Artificial Recharge Through a Well Tapping Basalt Aquifers at The Dalles, Oregon

GEOLOGICAL SURVEY WATER-SUPPLY PAPER 1594-E

Prepared in cooperation with the city of The Dalles

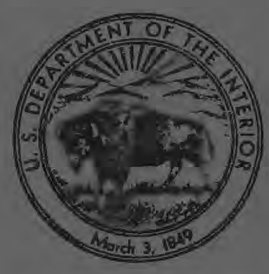


Artificial Recharge

\section{Through a Well Tapping}

Basalt Aquifers at

The Dalles, Oregon

${ }^{`} y$ B. L. FOXWORTHY and C. T. BRYANT

ARTIFICIAL RECHARGE OF GROUND WATER

SEOLOGICAL SURVEY WATER-SUPPLY PAPER・1594-E

Prepared in cooperation with

the city of The Dalles

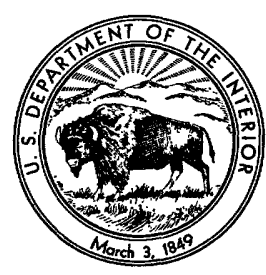

TNITED STATES GOVERNMENT PRINTING OFFICE, WASHINGTON : 1967 
UNITED STATES DEPARTMENT OF THE INTERIOR

STEWART L. UDALL, Secretary

GEOLOGICAL SURVEY

William T. Pecora, Director 


\section{CONTENTS}

\begin{tabular}{|c|c|}
\hline & Page \\
\hline 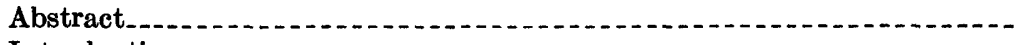 & E1 \\
\hline troduction & 2 \\
\hline Purpose and scope of the investigation & 2 \\
\hline Location and extent of the area & 3 \\
\hline Related investigations & 3 \\
\hline Acknowledgments & 6 \\
\hline Well-numbering system & 6 \\
\hline eologic and hydrologic features of the area. & 7 \\
\hline The Dalles ground-water area & 7 \\
\hline Occurrence of water in the basalt & $\mathbf{9}$ \\
\hline Ground-water recharge and movement & 10 \\
\hline Water-level fluctuations & 11 \\
\hline urce and treatment of the recharge water & 12 \\
\hline ethods of study and equipment & 13 \\
\hline Preliminary evaluation & 14 \\
\hline Hydraulic character of the aquifer & 14 \\
\hline Adequacy of supply of recharge water & 15 \\
\hline Chemical and physical compatibility of the waters & 16 \\
\hline Chemical compatibility & 16 \\
\hline Physical compatibility & 17 \\
\hline Sediment in the recharge water & 18 \\
\hline Air in the recharge water & 18 \\
\hline Biological suitability of the recharge water & 20 \\
\hline Recharge well and accessory equipment & 20 \\
\hline Observation wells & 21 \\
\hline Experimental procedures and instruments & 23 \\
\hline echarge and pumping tests & 24 \\
\hline gnificance of the tests & 29 \\
\hline Changes in the physical and chemical character of the ground water- & 29 \\
\hline Specific conductance and temperature & 29 \\
\hline Dissolved oxygen & 33 \\
\hline Effects on the aquifer and the recharge well & 34 \\
\hline Buildup of water levels & 34 \\
\hline Specific capacity & 35 \\
\hline Recovery of injected water & 37 \\
\hline Condition of pumping equipment & 38 \\
\hline Methods and techniques for further artificial recharge & 38 \\
\hline Conclusions & 39 \\
\hline & 42 \\
\hline
\end{tabular}




\section{ILLUSTRATIONS}

Plate 1. Hydrographs of the recharge well (1N/13-4F1) and five observation wells........... In pocket

Figure 1. Map showing the area of this investigation ........ E4

2. Map showing locations of wells and water-supply facilities used in this investigation

3. Diagram showing well-numbering system

4. Schematic diagram showing pump and water system at

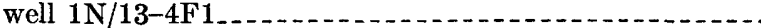

5-7. Graphs showing changes in-

5. Specific conductance of water from the recharge well_

6. Temperature of water from the recharge well.......

7. Dissolved-oxygen content of water from the recharge well

\section{TABLES}

TABLE

1. Summary of recharge and pumping tests, well $1 \mathrm{~N} / 13-4 \mathrm{~F} 1$.

2. Records of selected drilled wells in the Dalles area.......

3. Drillers' logs of wells

4. Chemical analyses of waters from the Dalles area ......

5. Suspended sediment in waters sampled during artificial recharge study at The Dalles...... 


\title{
ARTIFICIAL RECHARGE OF GROUND WATER
}

\section{ARTIFICIAL REGHARGE THROUGH A WELL TAPPING BASALT AQUIFERS AT THE DALLES, OREGON}

\author{
By B. L. Foxworthy and C. T. Bryant
}

\begin{abstract}
In the Dalles area, Oregon, an increase in pumpage from wells that tap permeable basalt aquifers has caused serious year-to-year declines in ground-water levels. To determine the feasibility of artificial recharge as a means of increasing the available supplies of ground water and to develop techniques applicable to a municipal program of artificial recharge, a series of artificial-recharge tests was conducted jointly by the city of The Dalles and the U.S. Geological Survey from autumn of 1960 to spring of 1961. A total of 81.4 million gallons of surplus water from the city's Mill Creek supply was injected under pressure into one of the municipal wells through the existing discharge line and pump column during four periods ranging in duration from 8 hours to more than 25 days at an average injection rate of about $1,500 \mathrm{gpm}$ (gallons per minute). The recharge water was filtered, chlorinated, and fluoridated prior to injection; preliminary tests showed it to be chemically compatible with the native ground water and free of harmful bacteria. The temperature of the recharge water was cooler than the normal ground water by $13^{\circ}$ to $25^{\circ} \mathrm{F}$.

As a result of the injection, the specific capacity of the well (ratio of pumping yield to drawdown) was reduced temporarily, owing to (1) increased viscosity of the ground water caused by the cooling effect of the recharge water, (2) clogging of the water-bearing zones near the well by bubbles of air coming out of solution in the recharge water, and (3), in one case, clogging by a chemical floc that was in the recharge water. After the last two periods of injection, of 10-day and 25-day durations respectively, it was necessary to surge the well by intermittent pumping to restore its specific capacity.

The artificial recharge had no serious deleterious effects on the quality of the ground water. Sediment that was injected was almost entirely removed from the recharge well during pumping and surging, and the bacteriological quality of the ground water did not deteriorate. The principal chemical and physical effects on the water were a general improvement in chemical quality over that of the native ground water and a lowering of the temperature.

The injected water spread widely and rapidly through the highly permeable aquifers, and the mound of artesian pressure that built up during periods of injection dissipated rapidly. No residual buildup of levels was measurable, even in the vicinity of the recharge well, within a few days after injection was
\end{abstract}


stopped. However, the geologic and hydrologic conditions preclude the escape of substantial amounts of recharge water from the ground-water subbasin.

The results are considered to be proof of the technical feasibility of artificially recharging the basalt aquifers through wells, although the methods and equipment used during these experiments should be modified for a long-term program of artificial recharge.

\section{INTRODUCTION}

\section{PURPOSE AND SCOPE OF THE INVESTIGATION}

The area of The Dalles, Oreg., is one of two small localities that have been designated as "critical ground water areas" by the Oregon State Engineer. The summer flow of the small streams that enter the area is fully appropriated, and large-yield wells are used for most of the industrial, irrigation, and public water supplies. As a result of large withdrawals from the wells in the area, ground-water levels declined progressively ( $p$. E12) for at least the 9 years preceding 1966. The declining water levels made apparent the conclusion that unless additional water was added to the ground-water system, withdrawal of ground water at the present rate soon would become unfeasible. Some wells in the area had to be deepened, and the pumps in several of the wells had to be lowered to follow the declining water level.

Four possible methods exist for supplying additional water to help meet the demand: (1) Importing surface water from the Columbia River or from smaller streams outside the area, (2) constructing surface reservoirs on the smaller streams to store flood runoff, (3) prospecting for ground-water sources that are deeper and hydraulically separate from those that supply the existing wells, and (4) artificially recharging, or replenishing, the ground-water body tapped by existing wells. The purpose of this investigation was to determine the feasibility of, and to develop techniques applicable to, the fourth method of increasing the available supplies-artificial recharge.

Because the depleted zones in the ground-water body are moderately deep artesian zones whose recharge areas are not known precisely, the only method of artificial recharge that was considered is direct injection of water through wells tapping those zones. Where feasible, subsurface storage of water by this method of artificial recharge has certain advantages over storage in surface reservoirs. For example, subsurface injection does not require major structures to impound or control the water; therefore, initial costs are generally much lower. Furthermore, the land above the ground-water reservoir so recharged is virtually all available for other uses, in contrast to the inundated land beneath surface reservoirs. Also, water stored underground is not subject to evaporation and is generally less susceptible to pollu- 
tion and seasonal temperature changes than is water in surface reservoirs. These apparent advantages, however, may be diminished by the absence of one or more of the conditions (p. E13) generally required for successful subsurface injection and evaluated for the Dalles area in this study.

The main elements of the investigation were a series of experiments wherein water from the Dalles municipal surface-water supply was injected into one of the city's wells through the existing turbine pump and pipelines. Before injection began, an aquifer test was made to determine the normal capacity of the recharge well, the hydraulic character of the aquifer in the vicinity of the well, and the degree of interconnection between the recharge well and adjacent wells. The ground water and the recharge water from the city's system were tested for physical and chemical character and bacteriological quality, and the results of those tests were compared to predict the compatibility of the waters upon mixing. Recharge was accomplished during four separate periods, each longer than the preceding one. Each period of recharge was followed by at least one pumping test to determine the effect of the recharge on the capacity of the well and on the character of the water in the vicinity of the well. Water levels in five observation wells in the vicinity of the recharge well were measured during the pumping tests and throughout the period of inrestigation. The equipment and methods that were used are described in a subsequent section of this report.

The investigation was financed cooperatively by the U.S. Geological Survey and the city of The Dalles, and personnel of both agencies participated in the collection of the field data. Fieldwork was begun in October 1960 and continued into June 1961.

\section{LOCATION AND EXTENT OF THE AREA}

The Dalles is in north-central Oregon on the south bank of the Columbia River, which there forms the boundary between Oregon and Washington (fig. 1). Mill Creek, a northeastward-flowing tributary of the Columbia, passes through the city. The wells from which the data were gathered during this investigation are within and southwest of the city limits (fig. 2). All the wells pertinent to this study are within "The Dalles Critical Ground Water Area" (fig. 1) designated by the Oregon State Engineer. The city's Jordan Street well, into which water was injected, is about 1 mile west of the city's center.

\section{RELATED INVESTIGATIONS}

Although artificial recharge through wells has been accomplished in many other parts of the country, a controlled study of such re- 


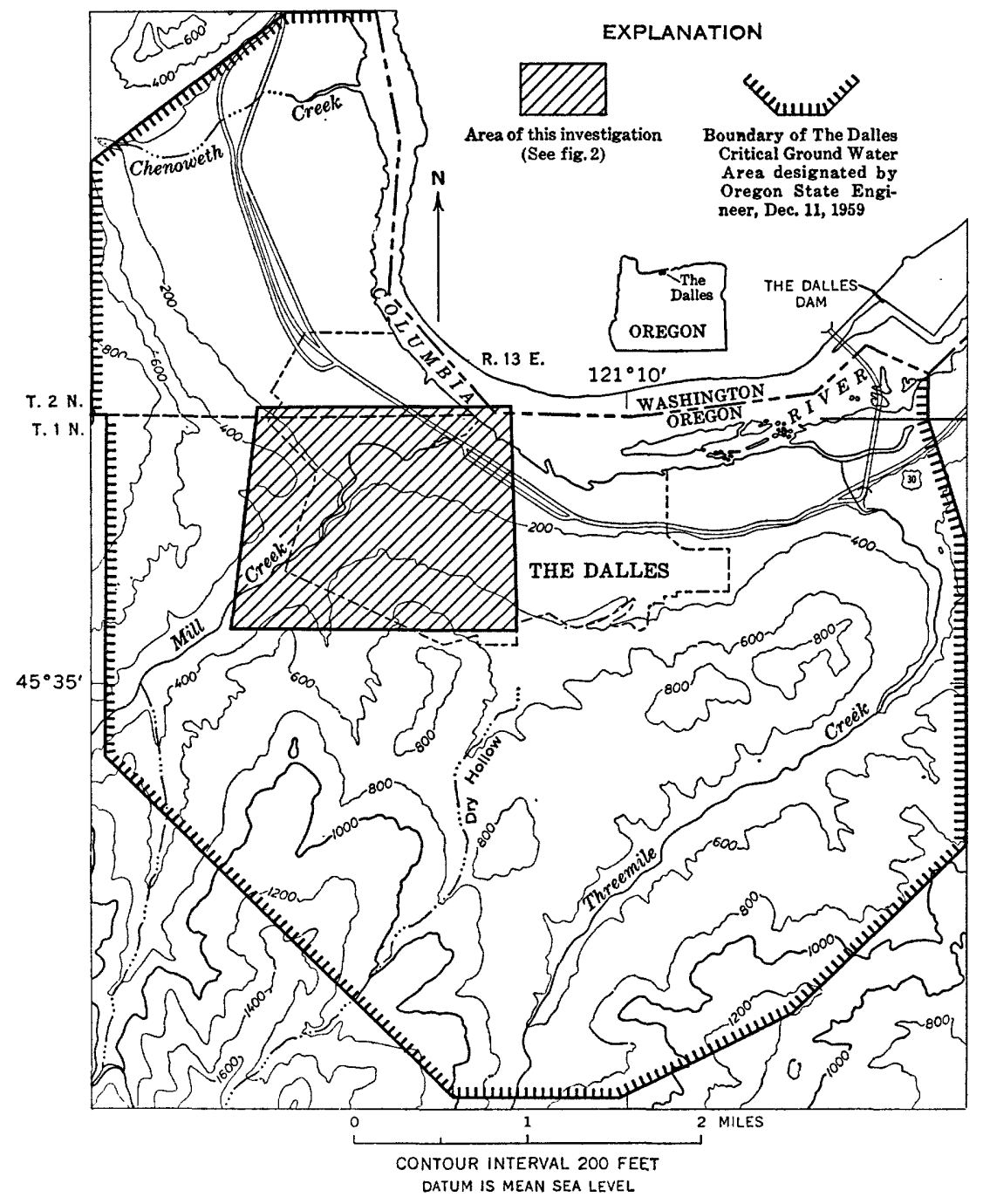

Figure 1.-Area of this investigation.

charge in wells that tap water-bearing zones in basalt had been made only once before the beginning of this investigation. The previous study at Walla Walla, Wash. (Price, 1961), where about 23 million gallons of surface water was injected into the basalt through a municipal-supply well of the city of Walla Walla at rates ranging from 630 to $670 \mathrm{gpm}$. The experiment was considered successful because the water injection caused a rise of the water level and increased the amount of ground water in storage in the vicinity of the well. How- 


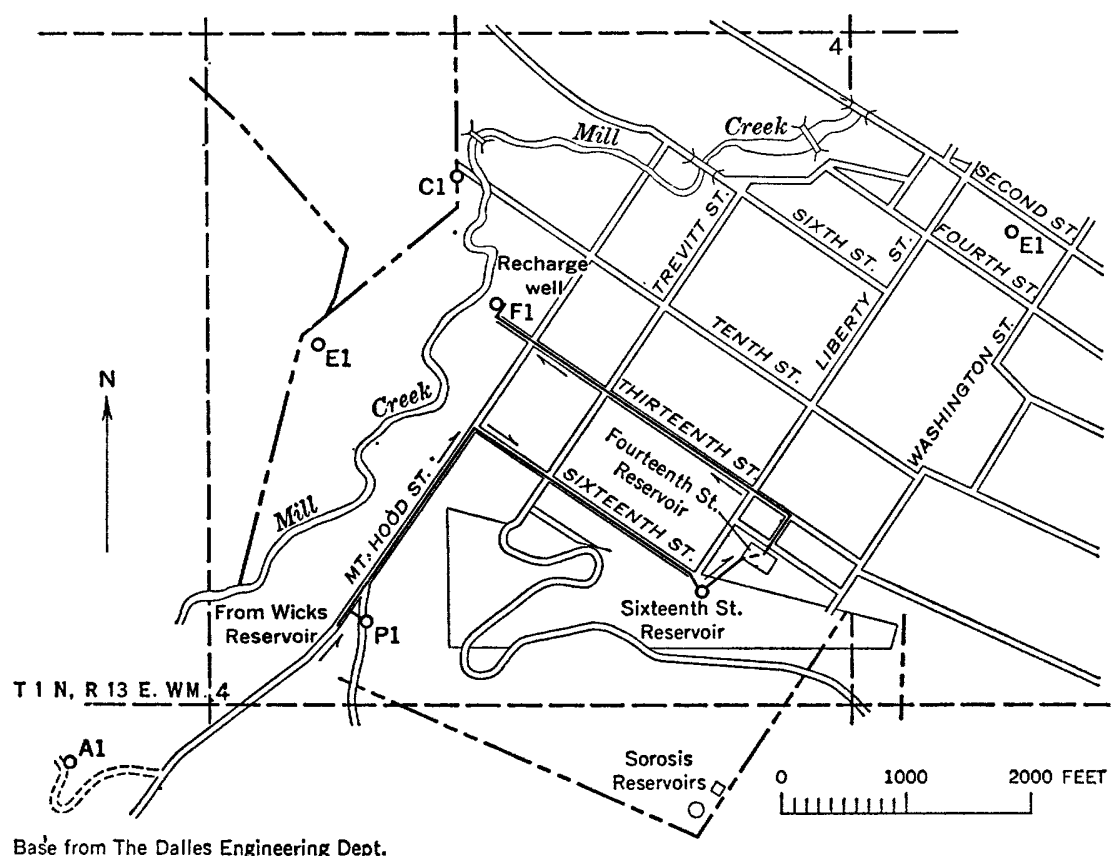

Bas'e from The Dalles Engineering Dept.

EXPLANATION

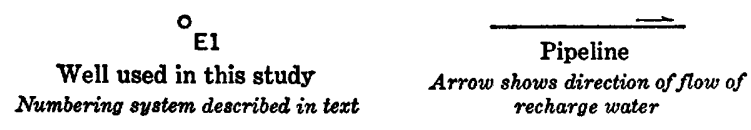

FIGURE 2.-Locations of wells and water-supply facilities used in this investigation.

ever, the injection caused a decrease in the yield and specific capacity of the recharge well, probably owing largely to partial clogging of the water-bearing materials in the vicinity of the well by entrained air. Experience and data gained during the Walla Walla experiment have proved valuable in the planning and conduct of experiments in this investigation.

At the time of this investigation, an exhaustive and well-documented series of subsurface-injection studies was nearing completion in the Grand Prairie region, Arkansas. Various aspects of those studies are described in the U.S. Geological Survey Water-Supply Paper 1615 , chapters A-G. Some of the preliminary results of the Arkansas studies provided helpful guidance in this investigation.

The geology and ground-water conditions of the Dalles area were first studied by Piper (1932), whose report includes records of some of the early wells, background hydrologic data, and a description of some of the geologic structures that affect the occurrence and movement of ground water in the area. 
The Dalles area is also included in two current studies. Mr. J. E. Sceva, of the office of the Oregon State Engineer, has begun a study to determine the relation between ground-water pumpage and waterlevel decline to aid in the effective management of the water resources of the area. As part of a broad investigation of the hydrology of the Columbia River Group, Mr. R. C. Newcomb, research geologist of the U.S. Geological Survey, has studied the effects that folds and faults in the rocks of the area have on the movement of ground water.

Data obtained from all these related studies have been made available to the writers and have been helpful in the planning and conducting of this investigation and in the preparation of this report.

\section{ACKNOWLEDGMENTS}

The investigation was facilitated by the assistance of many persons. Without the excellent cooperation of the Dalles city officials, notably Mr. C. Dean Smith, city manager, and Mr. James Manes, superintendent of public works, the collection of many important data would not have been possible. Valuable assistance and information concerning the city's water supply were furnished by the firm of Cornell, Howland, Hayes \& Merryfield, represented by Messrs. Holly Cornell and James W. Poirot.

The I.O.O.F. (Independent Order of Odd Fellows) and Messrs. G. S. Williams and George Stadelman allowed the use of their wells for observation purposes. Water samples were analyzed for bacteriological quality by the public health laboratory of the Oregon State Board of Health. The friendly cooperation of all is gratefully acknowledged.

Special thanks is due Mr. Clifford Wilds, of The Dalles Water Department, whose outstanding work on data collection and local arrangements contributed greatly to the success of this study.

U.S. Geological Survey personnel who assisted the authors in the collection and compilation of data were Messrs. E. R. Hampton, P. Y. Jeffs, and Don Price.

\section{WELI-NUMBERING SYSTEM}

Wells discussed in this report are designated by symbols that indicate their location according to the rectangular system of land division. In the symbol $1 \mathrm{~N} / 13-4 \mathrm{~F} 1$, for example, the part preceding the dash indicates respectively the township and range (T. 1 N., R. 13 E.) north and east of the Williamette base line and meridian. Because most of the State lies south of the Williamette base line and east of the Williamette meridian, the letters indicating the directions south and east are omitted, but the letters " $W$ " and " $N$ " are included for 
wells lying west of the meridian and north of the base line. The first number after the dash indicates the section (sec. 4), and the letter (F) indicates a 40 -acre subdivision of the section as shown in figure 3 . The final digit is the serial number of the well within that 40 -acre tract. Thus, well $1 \mathrm{~N} / 13-4 \mathrm{~F} 1$ is in the $\mathrm{SE} 1 / 4 \mathrm{NW} 1 / 4$ sec. 4 , T. 1 N., R. 13 E. and is the first well in the tract to be listed.

In order to relate the well numbers to the local designations for the wells, both the well number and the local designation are given in the first few references to each well.

\section{GEOLOGIC AND HYDROLOGIC FEATURES OF THE AREA}

The functioning of any artificial-recharge operation, especially one involving injection through wells, is largely controlled by the geologic and hydrologic conditions and processes that prevail. Therefore, an understanding of the geologic and hydrologic features is necessary for adequate design, operation, and evaluation of artificial-recharge operations. In the Dalles area, the necessary information on local conditions is available largely due to the previous and current related studies (p. E3-E6).

\section{THE DALLES GROUND-WATER AREA}

The Dalles is in the northern part of a broad northward-plunging structural basin, the axis of which descends from the eastern flanks of the high Cascade Range to the vicinity of the Columbia River. The northern end of the basin terminates at the Columbia Hills, a few miles north of the river, in Washington.

This large basin contains several subbasins which are bounded largely by anticlines or by faults. These geologic structural features generally impede the lateral movement of ground water and tend to separate the subbasins hydraulically as well as topographically. All the wells used in this study are in one such hydrologic subunit. The boundaries of the subunit have not been determined precisely, but they probably encompass all or most of the "critical ground water area" designated by the Oregon State Engineer (fig. 1).

The oldest rock unit exposed in the area is the Columbia River Group of Miocene and Pliocene age. This unit comprises a thick sequence of accordantly layered lava flows and minor sedimentary beds between some flow layers. The basalt forms vertical bluffs along the Columbia River and in the city and is the bedrock for the region surrounding The Dalles. The Columbia River Group contains by far the most productive aquifers in the Dalles area and is tapped by all the large-yield wells in the area. 


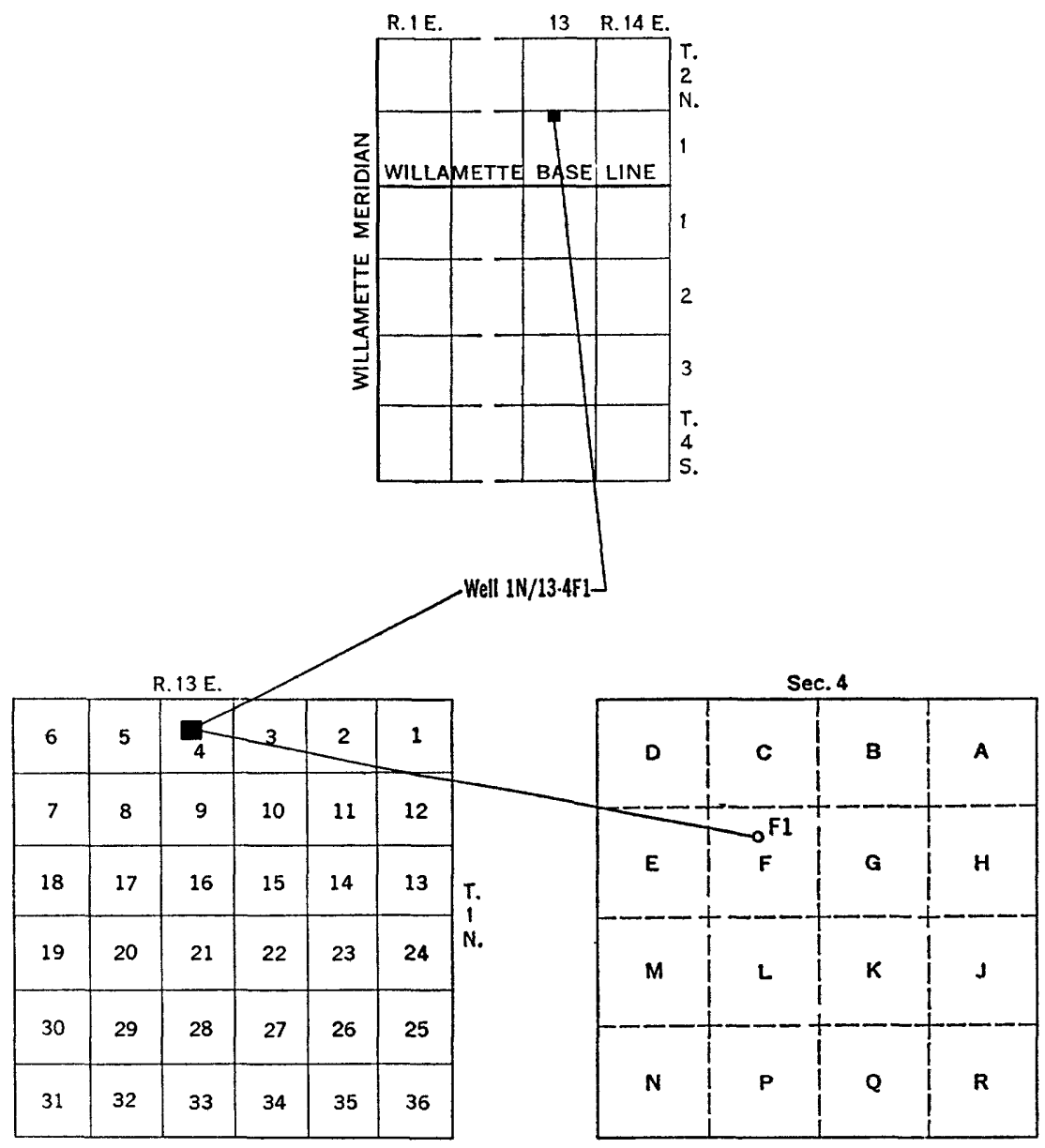

Figurb 3.-Well-numbering system.

The Columbia River Group is overlain by the Dalles Formation of Pliocene age in the higher parts of the area and by alluvium of Pleistocene and Recent ages along the channels of the Columbia River and the smaller streams (Piper, 1932, p. 120-127, 133-134, and pl.11). The Dalles Formation consists mainly of partly consolidated sandstone and conglomerate and contains much pyroclastic material. The alluvium consists of gravel, sand, and silt and represents flood-plain and terrace deposits. Neither the Dalles Formation nor the alluvium yields large amounts of water to wells in this area.

At least 30 moderate- to large-yield industrial, irrigation, and public-supply wells in the Dalles ground-water area tap aquifers in the Columbia River Group. The yields of the wells range from about 100 
to $2,500 \mathrm{gpm}$ and probably total more than 5 billion gallons $(15,000$ acre-feet) per year. The large withdrawals of ground water have caused a marked general decline of water levels since at least 1957 in wells that tap the basalt. (See p. E12.)

In January 1959, the State Engineer declared the area to be a "critical ground water area" (fig. 1). The orders issued by that official provided for (1) close regulation to ensure that the amount of ground water withdrawn did not exceed that allowed under the ground-water rights and to prevent unlawful diversions of ground water, (2) refusal of applications to appropriate additional ground water from the confined basalt aquifers tapped by the wells whose levels had declined, and (3) maintenance of records of the monthly withdrawal from each well. As of February 1966, the designation of the area as a "critical ground water area" and the accompanying orders were being contested in the courts, and the execution of those orders was being deferred pending the outcome of that contest.

\section{OCCURRENCE OF WATER IN THE BASALT}

Ground water may be defined as water that occurs under hydrostatic pressure below the land surface; it completely saturates or fills the pore spaces of the rock materials in which it occurs. The upper surface of a ground-water body, if unconfined, is called the water table, and its position is indicated by the level at which water stands in a nondischarging well.

In addition to the unconfined, or water-table type of condition, ground water occurs under confined, or artesian, conditions. Confined ground water occurs where an aquifer is overlain by a less permeable layer that retards the upward movement of the water, and the head of water in higher extensions of the aquifer causes pressure to be exerted on the base of the confining layer. Thus, in a well that taps an aquifer containing confined water, the water rises above the base of the confining layer. The imaginary surface coinciding with levels to which confined water rises in wells is called the piezometric surface.

Because ground water occurs in the openings, or interstices, in the rock materials, the amount of water contained in and the rate at which it can move through the rock materials depend largely upon the size and degree of interconnection of the interstices. The capacity of a rock material to transmit and yield water is usually referred to in terms of its permeability or transmissibility.

Ground water that is available for withdrawal from the basalt of the Columbia River Group occurs principally in permeable zones at and near the contacts between certain flow layers. In contrast, the central parts of the flow layers are relatively impermeable except where 
they are strongly jointed or fractured. In general, ground water can move relatively freely through the tabular interflow zones parallel to the flow layers, but it moves across the flows much less readily. The permeable interflow zones are not continuous everywhere; each may be discontinuous or may merge with another at the termination of an adjacent flow. Faulting or intense folding of the basalt may further interrupt the continuity of the permeable zones. Where faulting has occurred, the water-bearing strata may be crushed to an impermeable material or may be offset so that a permeable layer abuts an impermeable layer. Folding of the basalt causes the layers to shift along the interflow zones and in places may have crushed the once-permeable zones into a finer, less permeable material.

Ground water in the Columbia River Group in the Dalles area occurs under both confined and unconfined conditions. In addition, water in saturated zones in the basalt at places is held above an unsaturated zone by relatively impermeable strata. Water in such a zone is called perched ground water, and its upper surface is called a perched water table. All the large-yield wells in the Dalles ground-water area are believed to tap confined aquifers-permeable interflow zones in the basalt wherein water is confined by the dense central parts of the adjacent flow layers.

Although some of the large-yield wells in the Dalles area reportedly penetrated several water-bearing zones, the principal source of water for most is believed to be laterally extensive, highly permeable confined aquifer, or several confined aquifers that are sufficiently connected hydraulically to behave as a single unit. This aquifer complex has been termed "The Dalles Ground Water Reservoir" by the Oregon State Engineer.

\section{GROUND-WATER RECHARGE AND MOVEMENT}

The principal basalt aquifers tapped by wells in the area are recharged naturally by subsurface leakage from adjoining and overlying ground-water bodies, which in turn are recharged by infiltration from precipitation. Most of the precipitation that goes to recharge the basalt aquifers probably occurs in the highlands south of the Dalles area, where precipitation is much greater than the 13.8-inch yearly average measured near The Dalles.

From the recharge areas, the water moves toward the centers of pumping in and near the city. At most places in the area, the direction of movement in the confined aquifers can only be approximated because the hydraulic gradient-the slope of the piezometric surface-is gentle and because the altitudes at most of the wells are not precisely known. Also, water-level measurements from some wells in 
the area may be anomalous at times as a result of interbed leakage of ground water through uncased intervals of the wells.

Under natural (predevelopment) conditions, the overall movement of water in the principal aquifers undoubtedly was generally northward toward the Columbia River. Except during its flood stages that river, which constituted the hydraulic base level for the area, flowed at levels lower than the heads in the principal artesian aquifers. The relatively slow natural discharge from the principal aquifers occurred as upward leakage through the overlying basalt layers.

Under present (1966) conditions, discharge of water from the confined aquifers is mostly by withdrawal from wells. The artesian heads have been lowered drastically by pumping, and the Columbia River is now maintained at higher levels by Bonneville Dam (not shown). Thus, the possibility of subsurface migration of ground water from the Dalles ground-water area is virtually eliminated by the higher levels in the river and in adjacent ground-water bodies, as well as by the aforementioned structural barriers (p. E7).

Although the piezometric surface of the principal aquifers now stands lower than the level of the Columbia River throughout the year, apparently the river is not a major source of recharge to the aquifers. Water levels measured in the City Hall well (1N/13-3E1) from November 1926 to July 1930 (Piper, 1932, p. 159, pl. 18) had no fluctuations that could be correlated with changes in the stage of the Columbia River. Likewise, the detailed measurements of water levels made during this investigation indicated no clear-cut trends that could be correlated with fluctuations of the river levels. It is postulated, therefore, that some barrier to the movement of ground water, such as a relatively impermeable fault zone or a silt layer in the river channel, effectively prevents the infiltration of substantial amounts of water from the river to the artesian basalt aquifers beneath the city.

\section{WATER-LEVEL FLUCTUATIONS}

Water levels in wells that tap the confined basalt aquifers fluctuate naturally from high levels in the spring, when the greatest recharge from precipitation and snowmelt can be expected, to low levels in the late summer or early autumn, when there is least precipitation and runoff and greatest withdrawal from wells. Water-level measurements made during the period from October 1960 to June 1961 indicate that the highest water levels occurred during the third week in April 1961. (See pl. 1.) Measurements for this study had not yet begun during the period of lowest ground-water levels in 1960, which, according to data from the office of the Oregon State Engineer, occurred in September of that year. 
Superimposed on the seasonal fluctuations of the piezometric surface are short-term fluctuations that represent a response to changes in atmospheric pressure. Barometric measurements obtained by Piper $(1932$, p. 158, pl. 18) and during the present study, although not shown, indicate that the levels in some of the wells have a nearly perfect barometric response.

Other short-term fluctuations are small declines resulting from intermittent withdrawals from other wells that tap the same aquifer system and, during this study, rises in response to the artificial-recharge tests. The level in one well generally responds rapidly to pumping from another, even over considerable distances. During the pumping test that followed the second recharge test in this study, for example, the level in well 1N/13-3E1 (City Hall well), about 4,200 ft east of the well that was pumped (1N/13-4F1, Jordan Street well), began to decline measurably within 4 minutes after pumping was started. Rapid responses to changing pressures, such as those just noted, are characteristic in wells that penetrate confined aquifers.

As previously mentioned, the levels in wells that tap the confined basalt acquifers have been declining generally from year to year during at least the last 9 years. Water-level data furnished by The Dalles Water Department indicate that the decline first became noticeable sometime between the spring of 1952 and early summer of 1958. In April 1952 the water level in the City Hall well (1N/13-3E1) was about $24 \mathrm{ft}$ below land surface-only about $2 \mathrm{ft}$ lower than the level measured by Piper (1932, p. 177) in May 1930. However, by June 1958 the level had declined to about $51 \mathrm{ft}$ below land surface. The year-to-year decline may be determined as the difference between the springtime (highest) levels for successive years. Use of this method with data furnished by the office of the Oregon State Engineer indicated declines ranging from about 2 to $11 \mathrm{ft}$ between 1957 and 1958 in three wells measured during that period and from about 3 to $16 \mathrm{ft}$ between 1958 and 1959 in seven wells. In 1960, the springtime levels were slightly higher in seven wells than during the previous year, showed no change in five wells, but were lower by as much as $5 \mathrm{ft}$ in the three other wells for which comparative measurements were available. Between 1960 and 1962, levels declined in all 15 wells: the least decline was $3.5 \mathrm{ft}$; the greatest, $14.5 \mathrm{ft}$; and the average, $7.5 \mathrm{ft}$. The trend of water-level decline probably is due entirely to increased ground-water withdrawal.

\section{SOURCE AND TREATMENT OF THE RECHARGE WATER}

The water that was experimentally injected during this study was treated stream water from the Dalles municipal-supply system. The 
stream water, which constitutes the principal supply for the city, is from the South Fork of Mill Creek (fig. 1) and the upper reaches of Dog River (not shown). The supply from those streams meets or exceeds the city's needs during about half the year, although during short periods of excessive runoff the stream water is too turbid for public supply without treatment beyond the capacity of the existing filtration plant. During periods of deficient streamflow or excessive turbidity, the surface-water supply is supplemented or replaced by water from one or more of the city wells.

The flow of Dog River is diverted into Mill Creek through a 20-inch wooden pipeline 3 miles long; the combined flows are diverted from the South Fork of Mill Creek at Wicks Reservoir, about 8 miles southwest of the city where the treatment plant is located. During about 30 days each year, when the water quality deteriorates as a result of turbid storm runoff, the Wicks treatment plant adds coagulating materials-sodium aluminate and aluminum sulfate-to the water, which is then passed through a filter bed of coal and sand. During the rest. of the time no coagulating agent is added, but the water is filtered and chlorinated at the Wicks plant and fluoridated at lower reservoirs.

Two pipelines carry the water into the city distribution system. One pipeline transmits water to the Sorosis Reservoirs; the other carries water to the distribution system in the vicinity of Marx well (1N/13-4P1) and to the Sixteenth Street Reservoir (fig. 2). The lines also supply water for irrigation and domestic use to customers outside the city limits.

The Sixteenth Street Reservoir, an open concrete and asphalt structure having a capacity of 0.6 million gallons, supplies intermediatelevel distribution lines; also, all the Mill Creek water for lower levels of the system passes from this reservoir to and through the Fourteenth Street Reservoir. The Fourteenth Street Reservoir, which is an open concrete structure having a capacity of 3.2 million gallons, is the reservoir to which the recharge well is connected (fig. 2) and from which the recharge water was obtained.

\section{METHODS OF STUDY AND EQUIPMENT}

The success of any project attempting artificial recharge through a well is dependent upon many factors, some of them interrelated. Principal among these factors are (1) the hydraulic character of the aquifer tapped by the well, (2) the supply of water for recharge, (3) the chemical and physical compatibility of the recharge water and the native ground water, (4) the sediment content of the recharge water, (5) the amount of air that is dissolved in the recharge water or that becomes entrained during the flow of water into the well, and 
(6) the possible presence in the water of organisms that are diseaseproducing in humans or that are otherwise troublesome.

Some of these factors can be evaluated by methods now available; however, even under the most favorable conditions, and where the chemical and physical characteristics of both the native ground water and the recharge water are known reasonably well, it is often impossible to predict reliably how a subsurface-injection operation will function on a sustained basis. The least risk to expensive wells and equipment results if long-term subsurface injection is approached through a series of progressive, carefully evaluated injection experiments.

In this study, a preliminary evaluation was made to guide the injection experiments, to foresee and avoid possible problems, and to determine prerecharge conditions. The actual injection was accomplished in four separate periods, with sufficient sampling and monitoring to detect rapidly any deterioration of conditions. Each period of recharge was followed by at least one pumping test to determine the effects of the recharging on the capacity of the well and the character of the ground water.

\section{PRELIMINARY EVALUATION}

The preliminary evaluation included consideration of each of the major factors listed in the preceding section and necessitated the collection and interpretation of additional data as well as review of existing data. Most of the preliminary data are presented with the experimental data included in this report.

The suitability of surface water from the city's system for injection underground was evaluated in consultation with L. B. Laird, former district chemist of the Geological Survey for the Pacific Northwest, and E. J. Weathersbee, district sanitary engineer for the Oregon State Board of Health.

\section{HYDRAULIC CHARACTER OF THE AQUTFER}

One of the most fundamental requirements for successful subsurface injection is that the aquifer to be recharged be at least moderately permeable and preferably highly permeable. The large yields of the wells that tap the aquifer system of the Dalles ground-water reservoir (p. E8-E9) indicate that it meets this requirement. Additional information on the water-yielding character of the main aquifer in the vicinity of the recharge well was collected during the preliminary phases of this investigation.

On November 29 and 30, 1960, prerecharge pumping and recovery tests were made at the recharge well (4F1, Jordan Street well). The 
main purposes of the tests were to determine the response of the observation wells (p. E21) and to obtain prerecharge data on the yield characteristics of the recharge well and the adjacent aquifer for later comparison with similar data from tests following each of the recharge experiments (table 1 ).

The data from the prerecharge tests were used to derive rough estimates of the coefficient of transmissibility of the main aquifer. The coefficient of transmissibility is defined as the flow of water, in gallons per day, through a vertical strip of the aquifer $1 \mathrm{ft}$ wide extending the full saturated height of the aquifer under a unit hydraulic gradient, at the prevailing water temperature. It is expressed here as gallons per day per foot.

During an 8-hour pumping test on November 29, the Jordan Street well yielded about $2,340 \mathrm{gpm}$ with a drawdown of water level amounting to $23.4 \mathrm{ft}$; this represents a specific capacity (yield divided by drawdown) of about $100 \mathrm{gpm}$ per $\mathrm{ft}$. Drawdown at observation well $3 \mathrm{E} 1$, whose specific capacity is about $455 \mathrm{gpm}$ per $\mathrm{ft}$, was analyzed by the nonequilibrium method of Theis $(1935$, p. 520$)$; this analysis suggested a coefficient of transmissibility of about 1 million gallons per day per foot. Analysis of the recovery of water levels in the recharge well (4F1) by the recovery method developed by Theis (1935, p. 522; Wenzel, 1942, p. 95) indicated a coefficient of transmissibility of about 320,000 gallons per day per $\mathrm{ft}$. Because local conditions differed substantially from the conditions assumed in the analytical methods (Wenzel, 1942, p. 87-88), the values derived indicate only approximately the transmissibility of the aquifer at the two wells but serve to suggest the range of transmissibility of the aquifer.

\section{ADEQUACY OF SUPPLY OF RECHARGE WATER}

Water in excess of the city's demand is available in the Mill Creek system during about 6 months of each year, usually from sometime in October to sometime in April or May. However, during part of that period, usually for only a few days at a time, the surface water is too turbid to use, and ground water is substituted for the entire surface-water supply.

If 2 million gallons of water per day from the city's water system could be injected into the well for 180 days from October to April, the total recharge would amount to 360 million gallons, or about 1,100 acre-ft per year. Even if the population of The Dalles increases, that amount of good-quality surplus stream water probably can be made available for artificial recharge during most years in the foreseeable future. This projected annual amount of recharge water is equivalent to the volume of a surface reservoir having an area of 40 
acres and an average water depth of about $28 \mathrm{ft}$. Thus, the injection of water through the Jordan Street well, if successful for prolonged periods in the amounts mentioned, would constitute a substantial supplement to the natural recharge until the population expands to a point where appreciable volumes of surplus water will no longer be available for injection.

\section{CHEMICAL AND PHYSTCAL COMPATYBILTTY OF THE WATHRS}

For optimum injection through wells, the intended recharge water must be chemically and physically compatible with the native ground water. It has been generally assumed that if the ground water and the recharge water have some similar chemical and physical characteristics, they will be compatible and consequently will mix without producing a precipitate or other undesirable result. However, it is not always possible to determine whether two waters are compatible by using only known factors. Factors that may be difficult to measure, unless observations could be made inside the aquifer, may determine whether the waters are compatible. Small changes of $\mathrm{pH}$, Eh (reduction-oxidation potential), temperature, pressure, the presence of certain dissolved gases, and exposure to air can cause precipitation of chemical constituents such as iron, aluminum, manganese, calcium, and carbonate. If such precipitates form in appreciable amounts, they may be detrimental to future aquifer performance. For example, if iron is present in the ground water in the ferrous state, it is subject to oxidation if oxygen-rich water is injected into the aquifer and will form ferric hydroxide which is practically insoluble at normal $\mathrm{pH}$ values of ground waters (Hem, 1959, p. 59).

\section{CHEMICaL COMPaTIBILITY}

Prior to the first recharge test, the characteristics of the water from the Fourteenth Street Reservoir and from the recharge well were determined by analyses of samples collected on October 27, 1960 (table 4). On the basis of these and later analyses, the water from the city supply and the ground water, with minor exceptions, appear chemically well suited for mixing.

Although the specific conductances of the two waters differ to a rather large degree -470 micromhos for the native ground water and an average of about 90 micromhos for the surface water-the major chemical constituents for both waters were generally similar with regard to percentage composition except for silica and dissolved oxygen.

The surface water contained about 11 to $14 \mathrm{ppm}$ (parts per million) of dissolved oxygen, in contrast to only about $1 \mathrm{ppm}$ in the native 
ground water (table 4). However, owing to the low concentrations of iron in the ground-water- $0.07 \mathrm{ppm}$ in a sample from well $4 \mathrm{~F} 1-$ (table 4), precipitation of iron was not expected to be troublesome.

Of the samples collected on October 27, 1960 (table 4), the surface water contained $38 \mathrm{ppm}$ of silica, which was 43 percent of the total dissolved solids (residue on evaporation), whereas the ground water contained $62 \mathrm{ppm}$ of silica, which was 19 percent of the total dissolved solids. However, this difference was not expected to cause trouble during the artificial-recharge experiments.

\section{PHYSICAL COMPATIBILITY}

Two physical properties that relate to the compatibility of the recharge water and native ground water are viscosity and density. Both viscosity and density are inversely proportional to temperature-as the temperature increases, viscosity and density decrease.

If cold water is injected into a well that taps a ground-water body of moderate temperature, the injected water tends to settle toward the bottom of the aquifer. Owing to its greater density and viscosity, the colder recharge water tends to remain separated from the native ground water. In aquifers that are thin or that have small interstices, the tendency for density-layering may be largely overcome by dispersion of the water as it flows outward from the well. However, in thicker, highly permeable aquifers, such as are tapped by the largeyield wells in the Dalles area, a definite stratification of waters having different density might be expected.

Cold water has greater viscosity and, therefore, moves through the interstices of an aquifer less freely than warm water. Thus, if the temperature of water in an aquifer is reduced, the effective permeability of that aquifer also will be reduced. This means that, for a given pumping yield, the drawdown of water level in a well tapping that aquifer will become greater as the temperature of water in the aquifer becomes cooler; conversely, if the pumping level were to be held constant, the yield of the well would decrease as the water became cooler (Sniegocki, 1960, p. 1490).

The temperature of the ground water at the recharge well was $62^{\circ} \mathrm{F}$ on October 27, 1960, whereas the water in the Fourteenth Street Reservoir was $10^{\circ} \mathrm{F}$ cooler. During the injection experiments planned for winter and early spring, the surface water would be still cooler. Thus, because of the greater viscosity of the colder recharge water, a substantial reduction could be expected in the specific capacity of the recharge well following the injection of the colder water. However, that reduction would be only temporary and would gradually diminish as more of the recharge water was withdrawn from the vicinity of the well and the warmer native ground water moved in. 


\section{STDIMENT IN THE RECHARGE WATER}

The presence of even a small amount of sediment in water that is injected into a well can, in time, seriously clog the well and the aquifer materials adjacent to the well. The degree of clogging that will result from the injection of sediment-bearing water depends not only upon the amount of sediment but also upon the composition of the sediment, the size of the particles, the composition of the aquifer materials, and the size of the interstices in the aquifer.

However, nearly all the sediment is removed from the surface-water supply of The Dalles by filtration at Wicks treatment plant before the water enters the pipelines leading to the city reservoirs. Any sediment remaining has an additional opportunity to settle when the water moves through the Sixteenth Street and Fourteenth Street Reservoirs. Because of this arrangement, most of the water used for recharge during this study contained very little sediment.

Four samples of water from the Fourteenth Street Reservoir, collected prior to recharge (October 26 and 27 and November 29 and 30, 1960), had very low sediment concentrations-from 0 to 3 ppm (table 5 ), or 0 to 8 pounds per acre-ft of water. A sample collected from the recharge well on October 27, 1960, contained no detectable sediment. On the basis of these determinations, it was concluded that the amount of sediment entering the well with the recharge water was negligible because it would not cause serious clogging of the aquifer.

\section{AIR IN THE RECHARGE WATMR}

Air introduced into a well during recharge may lessen the watercarrying capacity of an aquifer by both physical and chemical processes. Gases in the air may react chemically with native ground water to produce precipitates that can clog an aquifer or well screen. Also, even a relatively small volume of air, in the form of bubbles, may markedly reduce the permeability of an aquifer. The bubbles not only occupy space in the interstices, thereby reducing the effective porosity, but they may effectively block the main routes along which water moves toward the well (Orlob and Radhakrishna, 1958, p. 648). The bubbles are normally tightly held to the aquifer materials by molecular attraction, and high velocities are required for their displacement. Under normal conditions, air bubbles in an aquifer dissolve very slowly, even in water that has a low dissolved-air content.

The productivity of a well at Walla Walla, Wash., was materially reduced following injection of water containing dissolved and entrained air (Price, 1961, p. 28-29). The likelihood of experiencing similar problems at The Dalles was, therefore, examined in some detail. 
Air can enter the aquifers when dissolved in the water injected into the well and when entrained in the recharge water during its flow into the well. For air dissolved in fresh water, the ratio of oxygen, nitrogen, and other atmospheric gases is virtually constant at normal water temperatures unless the oxygen content is reduced or increased by biological activity. However, the fact that the oxygen content of the water in the Fourteenth Street Reservoir was always virtually at the saturation point suggests that biological activity could be discounted. Therefore, the amount of dissolved air in the water from the reservoir was computed from the determinations of dissolved oxygen in table 4.

Air dissolved in water in a state of equilibrium tends to come out of solution if the water becomes warmer or if the pressure on the water decreases. Conversely, if the temperature of the water decreases or the pressure increases, the air tends to remain in solution or more air can be taken into solution.

Water from the Fourteenth Street Reservoir, under 1 atmosphere of pressure, was to be injected through the suction pipe of the pump at a depth of about $194 \mathrm{ft}$ below land surface. With a moderate buildup of the water level in the well during injection, the recharge water would be released from the pump at a point in the well where the pressure is about 2 atmospheres. Once in the principal aquifer, the recharge water would be under the somewhat greater pressureabout 3 atmospheres-represented by the height of the static piezometric surface above the top of the aquifer, which is about $242 \mathrm{ft}$ below land surface. (See table 2.) This increased pressure, of course, would tend to keep the dissolved air and other gases in solution.

Although the recharge water would be warmed somewhat after injection, the effect of temperature increase-forcing air out of solution-appeared likely to be more than offset by the effects of pressure increase-forcing air to remain in solution-and dilution of the recharge water to a lower concentration of dissolved air. The temperature effect, therefore, seemed to pose no problem.

Another possibility was that dissolved air might come out of solution as the recharge water flowed to and discharged into the well. In rapidly moving water, dissolved gases are likely to come out of solution at points of sharply increased velocity where pressure is reduced. Such pressure reduction occurs at sharp bends in pipes, valves, water meters, and any other constrictions of or projections into pipelines. The bubbles thus formed may be carried great distances without being redissolved in the water.

In its course from the Fourteenth Street Reservoir to the recharge well, the water would pass through several valves and two water meters 
(fig. 4); therefore, sharp pressure reductions were unavoidable. For this reason, the writers concluded that partial clogging of the aquifer by air bubbles might constitute a serious problem during the planned injection experiments.

If water is allowed to cascade freely into the well, large amounts of air may become entrained in the falling water and be carried out into the aquifer as bubbles. In the recharge tests at The Dalles, however, the water was to be injected under pressures ranging from about 50 to 70 pounds per square inch at the well head and discharged below the water level in the well. Thus, no opportunity for the entrainment of air in the recharge water was foreseen.

\section{BIOLOGICAL SUITABIHITY OF THE RECHARGE WATER}

Certain organisms can be troublesome if they are injected underground during recharge. Pathogenic bacteria, for example, can render a ground-water body unfit as a source of drinking water. Other organisms, the so-called nuisance bacteria, although not disease-producing in humans, may color the water, produce slimes or other objectionable products, and cause unpleasant taste and odor.

The Dalles surface-water supply is chlorinated at the Wicks treatment plant and is considered effectively free of pathogenic organisms when it enters the distribution system. The existence of nuisance bacteria was tested in a series of samples of (1) raw water from Mill Creek at the intake of Wicks Reservoir, (2) chlorinated water at the Fourteenth Street Reservoir, and (3) water pumped from the Jordan Street well. The samples were tested by the public health laboratory of the Oregon State Board of Health. Laboratory cultures of the water samples failed to reveal any nuisance bacteria in the water; therefore, the chance of well clogging or water deterioration due to nuisance bacteria seemed to be small.

Between October 28 and November 29, 1960, prior to recharge, three samples each of water from the recharge well and from the Fourteenth Street Reservoir were tested by the public health laboratory of the Oregon State Board of Health for the presence of coliform bacteria. The results showed that the well water and the recharge water from the city's supply conformed to accepted bacteriological standards of purity.

\section{RECHARGE WELI AND ACCESSORY EQUIPMENT}

Well 1N/13-4F1 (Jordan Street well) was the recharge well and the pumped well in tests made during this investigation. It is on the northwest side of Jordan Street between 12th and 13th Streets. The well is $299 \mathrm{ft}$ deep and is cased to a depth of $145 \mathrm{ft}$ with 18-in.- 
diameter casing. The principal aquifer is porous basalt in a zone 242$280 \mathrm{ft}$ below land surface. The well is equipped with a five-stage turbine pump driven by a 300 -horsepower electric motor. The nominal diameters of the turbine bowls and pump column are 15 and 12 in. respectively. The intake to the pump is through a cone-shaped wire strainer and a 12-in.-diameter tailpipe, the opening of which was at a depth of $194 \mathrm{ft}$ below land surface during the pumping and recharge operations. Discharge from the pump is through a 12 -in. pipe which joins the main pipeline beneath Jordan Street, about $60 \mathrm{ft}$ from the well. The discharge line is equipped with two totalizing water meters arranged to measure flow in either direction. Figure 4 is a schematic diagram of the equipment and water system in the vicinity of well $4 \mathrm{~F} 1$.

The controls for the system include electrical time-delay switches and solenoid-operated valves. One arrangement of these allows water to flow down the pump column and lubricate the shaft bearings for 30 seconds before the pump motor is activated. Also, the system is equipped with automatic solenoid-operated pressure-reducing valves on lines that bypass the discharge line during the operation of the check valve (fig. 4). Thus, when the pump is turned on, the discharge from the well is automatically diverted through a bypass line to a storm sewer for about 1 minute while the pressure behind the check valve builds up to a level near that in the water mains, after which time the check valve opens. Similarly, after the pump is shut off, water from the city supply is automatically allowed to flow through the bypass line around the check valve and through the pump column into the well for about 1 minute while the check valve closes. (See fig. 4). These arrangements afford maximum protection to the equipment during starting and stopping of the pump but adversely affected the collection of water-level data during critical periods of the pumping and recharge tests.

\section{OBSERVATION WELLS}

Throughout the tests, water levels were measured in the recharge well (4F1), in two other city wells (3E1 and 4P1), and in wells owned by the I.O.O.F. (4E1), George Stadelman (4C1), and G. S. Williams (8A1). Water-level measurements from the wells are shown graphically in plate 1 . The records and drillers' $\operatorname{logs}$ of the wells are presented in tables 2 and 3 respectively.

Levels in well 3E1 were measured with a steel tape; wells $4 \mathrm{C} 1$ and $8 \mathrm{~A} 1$ had semiautomatic water-level recorders installed. Measurements from those three wells are considered to be accurate to about \pm 0.02 ft. Levels in wells $4 \mathrm{E} 1,4 \mathrm{~F} 1$, and $4 \mathrm{P} 1$ were measured by existing air 


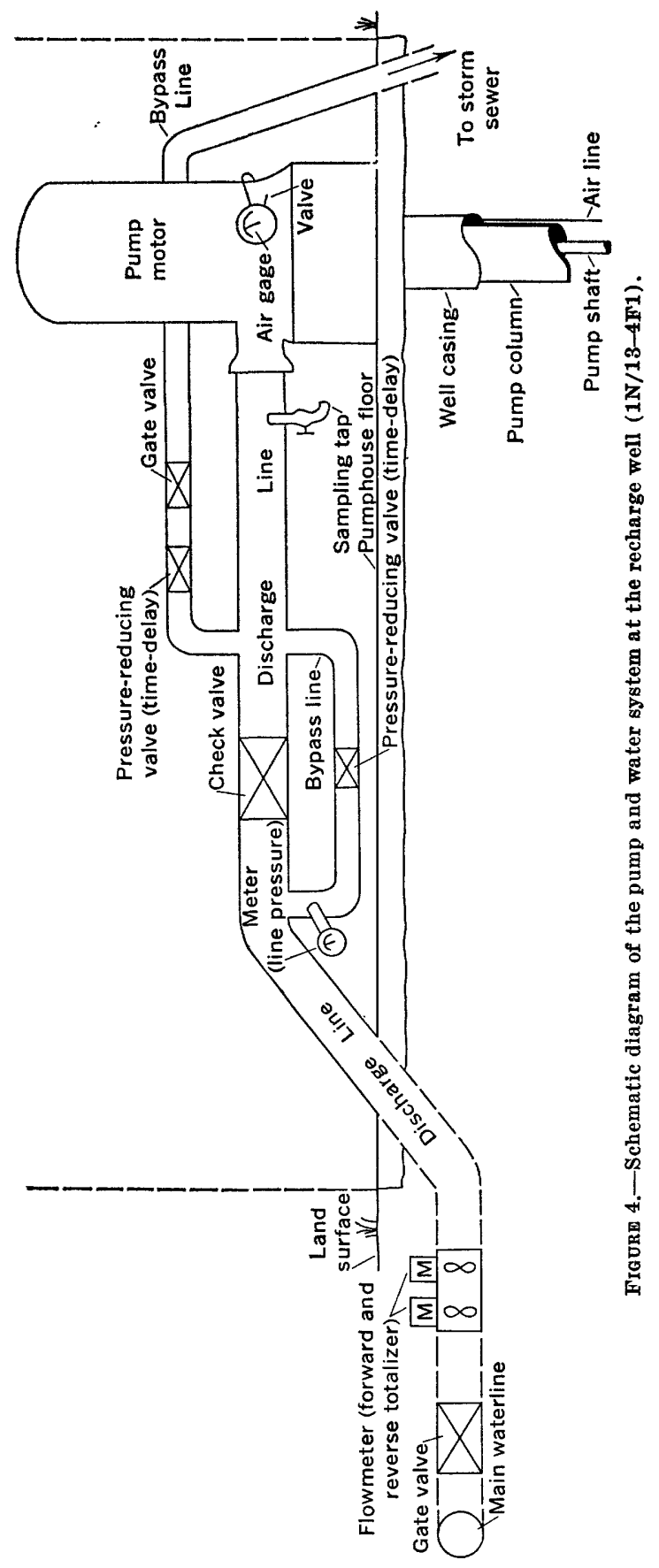


lines and pressure gages because there was no access for direct measurement. The air gage at well $4 \mathrm{~F} 1$ probably has a sensitivity adequate to indicate water-level changes of about $0.1 \mathrm{ft}$.; the other gages apparently are somewhat less sensitive.

Wells $3 \mathrm{E} 1,4 \mathrm{C} 1$, and $8 \mathrm{~A} 1$ were not pumped during the period of the recharge experiments. Well $4 \mathrm{P} 1$ was pumped several times during the period of the tests to replace turbid stream-water supplies. However, pumping did not interfere with the tests at the recharge well to any important degree. Well 4E1 was pumped once during the latter part of recharge test 4 ; however, the pumping did not interfere with the interpretation of the test results.

Well 8A1, which is farther from the recharge well than are the other observation wells, was selected as the control well to provide data on natural trends and fluctuations of ground-water levels. However, that well and the other observation wells responded to the longer periods of artificial recharge (pl.1).

\section{EXPERIMENTAL PROCEDURES AND INSTRUMENTS}

From December 21, 1960, to April 21, 1961, water from the Fourteenth Street Reservoir was injected into well $4 \mathrm{~F} 1$ in four tests, of 8hour, 2-day, 10-day, and 25-day durations. The first two recharge tests were conducted by personnel of the Geological Survey and the last two, by personnel of The Dalles Water Department who consulted only occasionally with the authors. Each period of recharge was followed by at least one pumping test conducted jointly by personnel of the Geological Survey and the city.

During the first two recharge tests, temperature data and various samples for chemical analyses were collected according to a prearranged schedule. During the later periods of recharge, some of the sampling and measurements were omitted. No samples were collected during the third recharge test, and only samples for determination of sediment content were taken during the fourth.

Water samples for use in determining chemical quality, dissolved oxygen, sediment content, and bacteriological quality also were collected during the pumping tests. Samples were taken for determination of bacteriological quality during the first and second recharge periods and the pumping tests that followed them. During those two pumping tests, part of the discharge water was continuously passed through a conductivity cell that was connected to a conductivity bridge; this arrangement allowed instantaneous measurement of the temperature and specific conductance of the water from the well.

The flow of water during recharge and pumping was measured by a pair of totalizing flow meters equipped with electrical transmitters 
connected to another totalizing meter and a recording rate meter in the wellhouse. The flow of recharge water to the well was adjusted only slightly by means of gate valves located beneath Jordan Street.

The water samples, except those used for bacteriological determinations, were analyzed in the Geological Survey laboratory at Portland, Oreg., by standard methods and largely by the junior author. The results of most detailed and partial chemical analyses are presented in table 4, and sediment determinations are shown in table 5.

\section{RECHARGE AND PUMPING TESTS}

In the following discussion of the individual experiments, the recharge tests are designated by the numbers $1-4$. The pumping tests that followed each period of recharge are assigned corresponding numbers, with letter designations added in the cases of tests involving more than one period of pumping. Significant data from the tests, as well as from the prerecharge pumping test, are summarized in table 1.

During the first recharge test (December 21, 1960), about 733,000 gallons was injected at an average rate of $1,520 \mathrm{gpm}$. The maximum buildup of water level in the well was $12.8 \mathrm{ft}$ above the prerecharge static level. Thus, the specific capacity-rate of injection divided by buildup-was about $119 \mathrm{gpm}$ per $\mathrm{ft}$. When injection was stopped, the ground-water mound in the vicinity of the well dissipated rapidly; the water level in the well declined to the prerecharge static level within 56 minutes. The sediment content of the recharge water was about $13 \mathrm{ppm}$ initially but declined rapidly to near zero.

Virtually all the sediment injected during the first recharge test probably was removed from the well during the early part of the subsequent pumping test 1 . During that pumping test, the sediment content 4 minutes after pumping began was about $110 \mathrm{ppm}$, but after 25 minutes the average sediment content for the duration of the test was less than $1 \mathrm{ppm}$ (table 5). The specific capacity near the end of pumping test 1 (December 22,1960) was about $87 \mathrm{gpm}$ per ft, or about $13 \mathrm{gpm}$ per ft less than the specific capacity of the well during the prerecharge pumping test. At that time the temperature of the water being pumped was $59^{\circ} \mathrm{F}$, or $3^{\circ}$ colder than the temperature of the native ground water and $16^{\circ}-17^{\circ}$ warmer than the water injected during the previous recharge period.

During recharge test 2 (January 24-26, 1961), the specific (recharge) capacity, about $124 \mathrm{gpm}$ per ft, was greater than for any other of the sustained tests. Within about $3 \frac{1}{2}$ hours after injection ceased the water level in the recharge well declined to the static position it had before this recharge. Virtually no sediment was detected in the water during recharge, or during the pumping test that followed. 


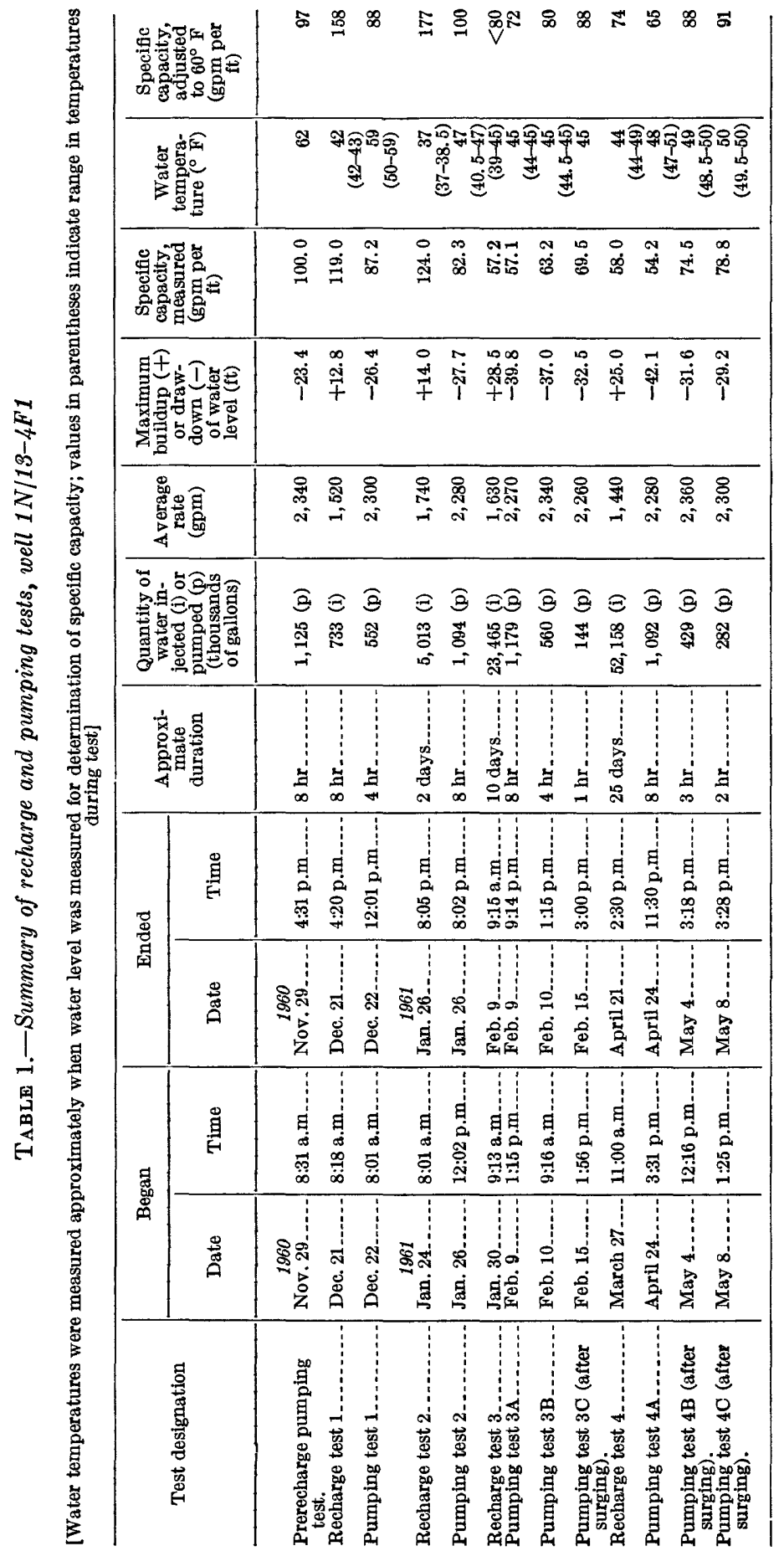


Pumping test 2 (January 26, 1961) was begun about 4 hours after the second period of recharge ended and was continued for 8 hours. During that test, as during the other pumping tests, the water level in the well, and thus the specific capacity, tended to decline progressively throughout the period of pumping. However, the temperature of the water pumped increased progressively, and the lower viscosity of the warmer water tended to offset the declining level. In this test, the measured pumping level declined only $0.1 \mathrm{ft}$ during the last 4 hours of pumping, while the temperature of the water increased from $44.5^{\circ}$ to $47^{\circ} \mathrm{F}$.

Recharge test 3 lasted for 10 days. As is obvious from the comparatively low value of specific capacity (table 1), the aquifer did not accept the recharge water as readily during this test as during the recharge tests 1 and 2. This is also shown by the hydrograph of the recharge well (plate 1). At the end of the first day of recharge in test 3 (January 30,1961), the level of water in the recharge well was rising at the rate of about $0.8 \mathrm{ft}$ per day, and the specific capacity of the well for accepting water was about $130 \mathrm{gpm}$ per ft. However, as shown by plate 1, after that first day the rate of buildup of water level in the well increased greatly. For the remainder of the test, the rate of buildup was several times greater than it had been during the other recharge periods, and at times it exceeded $1.5 \mathrm{ft}$ per day.

A constant or increasing rate of buildup of water level in a recharge well may result from (1) progressive clogging of the well or aquifer by air bubbles, sediment, or other clogging agents, (2) a regional rise of water levels, (3) complex boundary effects involving lateral changes in the transmissibility of the aquifers, or (4) decreased effective aquifer permeability due to the greater viscosity of the water being injected. Of these possible causes, a regional rise in water levels was discounted, inasmuch as levels in none of the observation wells were rising nearly so rapidly. Also, although no samples of the recharge water were collected during this test, the normally small sediment content of the water previously injected suggested that sediment was not a likely cause of any clogging. The rate of injection was adjusted in an attempt to decrease the amount of dissolved air that might be coming out of solution; when that action failed to produce any noticeable decrease in the rate of buildup, the injection was allowed to continue for the rest of the planned 10-day period without further change. The rapid buildup was assumed to be the result of one or a combination of unavoidable natural factors, such as (3) or (4) above, the consequences of which did not have time to develop during the previous shorter periods of injection.

The serious nature of the clogging that occurred during this recharge test became apparent during the early part of pumping test $3 \mathrm{~A}$ (Feb- 
ruary 9, 1961). Pumping began 4 hours after the end of recharge test 3 and continued for 8 hours. Within a few seconds after the pump started, the water level in the well was drawn down beyond the lowest level recorded by the air gage-about $184 \mathrm{ft}$ below land surface-and possibly to or near the end of the suction pipe-about $194 \mathrm{ft}$ below land surface. After about 5 minutes of pumping, the pumping level began to rise and the yield of the well began to increase. Within 1 hour after pumping began, the pumping level had nearly stabilized, and a yield (about $2,250 \mathrm{gpm}$ ) had been achieved that was near the rate maintained for the remainder of the test (table 1).

Water samples collected during pumping test $3 \mathrm{~A}$ showed that the clogging probably was caused by floc in the water injected during the previous recharge period. Water samples collected 2-5 minutes after pumping began had an average sediment content of $618 \mathrm{ppm}$ (table 5 ), a turbidity of 300 on the Jackson candle turbidimeter, and an aluminum content of $25 \mathrm{ppm}$ (table 4). The sediment content of water from the well declined as pumping proceeded but did not drop to zero as had been the case during pumping tests 1 and 2. During test $3 \mathrm{~A}$, the sediment content after $71 / 2$ hours of pumping still was about $4 \mathrm{ppm}$.

The beginning of the rapid buildup of water level on the second day of recharge test 3 (January 31,1961 ) coincided with a marked increase in the turbidity of the raw Mill Creek water entering the Wicks treatment plant. The turbidity, which lasted throughout the remainder of this recharge test, was caused by sediment carried in the runoff from regionwide storms. During this period of turbidity, the normal treatment by filtration and chlorination at the Wicks plant was augmented by the addition of coagulating chemicals to the water before it passed through the filter. The addition of the chemicals-filter alum, $\mathrm{Al}_{2}$ $\left(\mathrm{SO}_{4}\right)_{3}$, and sodium aluminate, $\mathrm{NaAlO}_{3}$-can cause several complex chemical reactions (Am. Water Works Assoc., 1950, p. 134-136); the most fundamental reaction that produces aluminum hydroxide floc is shown in simplified form as follows:

$$
\mathrm{Al}_{2}\left(\mathrm{SO}_{4}\right)_{3}+6 \mathrm{NaAlO}_{2}+12 \mathrm{H}_{2} \mathrm{O} \rightarrow 8 \mathrm{Al}(\mathrm{OH})_{3} \downarrow+3 \mathrm{Na}_{2} \mathrm{SO}_{4}
$$

Under ideal conditions nearly all the coagulants and the sediment are trapped on the filter. However, during the third recharge test, some of the coagulated matter, and perhaps some of the dissolved coagulants, apparently passed the filter at the treatment plant and were carried into the well.

Pumping was resumed on the next day after test $3 \mathrm{~A}$. The rate of pumping during pumping test $3 \mathrm{~B}$ (February 10, 1961) was kept constant to determine how effective an additional period of steady-rate pumping would be for removing the remainder of the sediment in the well. As in the previous pumping test, as soon as the pump was started, 
the water level in the well dropped almost immediately to or below the lowest level indicated by the air gage-about $185 \mathrm{ft}$ below the gage-but quickly rose to about $176 \mathrm{ft}$ below land surface and then slowly declined as pumping continued. About 4 minutes after the start of this test, the water from the well contained about $18 \mathrm{ppm}$ of sediment; at the end of the test the water appeared to be clear.

On February 15, 1961, the well was surged by intermittent pumping for about 3 hours in an attempt to improve the specific capacity. During most of that time the pump was allowed to operate for 45 seconds and was then shut off for about 30 seconds to allow the water to cascade back down through the pump column and flush the well.

After surging, a short pumping test (3C) was begun. Because previous experience had shown that the specific capacity of the well did not change rapidly after about the first hour of pumping, the test was continued only for 1 hour. At the end of that period the drawdown was $32.5 \mathrm{ft}$ and the specific capacity about $70 \mathrm{gpm}$ per $\mathrm{ft}$, or about $6 \mathrm{gpm}$ per $\mathrm{ft}$ more than was indicated by test $3 \mathrm{~B}$. During this test, and also during the previous surging operations, a small amount of sand-sized basalt fragments was carried in the water pumped from the well.

Water having a sediment content low enough to be judged suitable for recharge did not again become available until shortly before March 27,1961 , when test 4 , the longest of the series, was begun. During the 25-day test, nearly 52.2 million gallons of water was injected into the aquifer at an average rate of $1,440 \mathrm{gpm}$. The buildup of water level in the well near the end of the recharge period was about $25 \mathrm{ft}$ and indicated a specific (recharge) capacity of $58 \mathrm{gpm}$ per ft. The water injected during this test ranged in temperature from about $44^{\circ}$ to $49^{\circ}$ F. In all 18 water samples collected at daily intervals from April 4 to 21 , the sediment content was 2 ppm or less.

On April 24, 3 days after the recharge was stopped, pumping test $4 \mathrm{~A}$ was begun. During the 8-hour period of the test, nearby 1.1 million gallons was pumped from the well at an average rate of $2,280 \mathrm{gpm}$. The drawdown measured near the end of the pumping test was 42.1 $\mathrm{ft}$, and the specific capacity was about $54 \mathrm{gpm}$ per $\mathrm{ft}$. During this test the temperature of the water pumped reached a high of $51^{\circ} \mathrm{F}$ very quickly after the pump was started, declined to a low of $47^{\circ} \mathrm{F}$ from $11 / 2$ to 4 hours after pumping began, and then gradually rose to $47.8^{\circ} \mathrm{F}$ at the end of the period of pumping. (See fig. 6.)

Just after the pump started, the water from the well contained $6 \mathrm{ppm}$ of sediment; about 9 minutes later, $94 \mathrm{ppm}$; about 4 hours after pumping started, $18 \mathrm{ppm}$; and $73 / 4$ hours after pumping started, 3 ppm. 
A few hours before the end of recharge test 4, the water in Mill Creek became turbid and coagulating chemicals were again added to the water flowing through the Wicks treatment plant. A small amount of chemical floc may have passed through the filter and reached the well before injection was stopped.

On May 4 and May 8, 1961, for about 2 hours each day the recharge well was again surged in the manner previously described. As before, pumping tests were conducted after each period of surging to detect any changes in the specific capacity. In pumping test $4 \mathrm{~B}$, after the surging operations on May 4, the measured specific capacity was about $75 \mathrm{gpm}$ per $\mathrm{ft}$. Pumping test $4 \mathrm{C}$, on May 8 , indicated a specific capacity of about $79 \mathrm{gpm}$ per ft. During all the surging operations and associated pumping tests made in May, considerable amounts of sediment, consisting of grains and flakes of basalt, were carried in the water pumped from the well. Some of the basalt flakes were as much as 1 centimeter in their maximum dimension.

\section{SIGNIFICANCE OF THE TESTS}

The data collected during this study allow evaluation of many of the immediate and short-term effects of the artificial recharge. Some possible effects, however, such as changes in chemical conditions within the aquifer, may not be determined from the information now available. The results of the experiments provide a basis for evaluating the technical feasibility of artificial recharge by injection through wells in the Dalles area. However, the ultimate success of long-term artificial recharge might rest largely upon cumulative effects that may not become apparent until recharge has continued for long periods or upon economic considerations beyond the scope of this investigation.

\section{CHANGES IN THE PHYSICAL AND CHEMICAL CHARACTER OF THE GROUND WATER}

The injection of water from the Fourteenth Street Reservoir into the Jordan Street well caused several significant changes in the water in the aquifers adjacent to the well. The kinds and magnitude of those changes were directly related to the amount and to the physical and chemical characteristics of the recharge water injected.

\section{SPECIFIC CONDUCTANCE AND TEMPERATURE}

Significant chemical changes in a water are generally refiected in its specific conductance, a measure of its capacity to conduct electrical current. The conductance varies with the concentration and degree of ionization of the minerals in solution and also with the tempera- 
ture of the water. In this report, values of specific conductance are expressed in micromhos per centimeter at $25^{\circ} \mathrm{C}$.

During pumping tests 1 and 2, a portable instrument was used to determine the specific conductance and the temperature of the water being pumped. This instrument detected significant temperature and chemical changes in the water and thus guided collection of samples for analysis. Figures 5 and 6 show, respectively, the variations in specific conductance as determined either in the field or laboratory and the temperature of water pumped during pumping tests 1, 2, and 4A.

The first water pumped from the recharge well after injection was expected to be similar to the recharge water; the similarity to native ground water was expected to increase gradually as pumping continued and more recharge water was removed from the vicinity of the well. As figure 5 shows, however, the specific conductance of the water from the well was relatively high during the first few minutes of pumping and then decreased for a considerable time before the expected rise began.

During pumping test 1 (fig. 5), the specific conductance (laboratory determination) of a sample collected 5 minutes after pumping began was 256 micromhos (table 4), which would correspond to a mixture of about 40 percent native ground water and 60 percent recharge water. Four minutes later, the first reading obtained from the field conductivity instrument indicated a specific conductance of 215 micromhos, or about 30 percent native ground water and 70 percent recharge water. The specific conductance continued to decrease until about 30 minutes after pumping began, at which time the ratio of native ground water to recharge water was about 20 percent; thereafter, specific conductance rose progressively until the end of the pumping test. Just before pumping was stopped, the specific conductance (laboratory determination) of the water being pumped was 323 micromhos. This value indicated that about 60 percent of the water then being pumped was native ground water and about 40 percent was recharge water.

The changes in specific conductance generally followed the same pattern during the initial pumping test after each period of recharge; however, during some of the pumping tests, the determinations of specific conductance were too few to show the changes clearly. Also, during pumping test $4 \mathrm{~A}$ (fig. 5), pumping apparently was not continued long enough to reach the upturn in specific conductance values.

The curves in figure 6 suggest that changes in water temperature followed the same trends as the specific conductance, although on a smaller scale. However, temperature measurements were not made sufficiently early during most of the pumping tests to define adequately the rapid changes in temperature that probably occurred. 


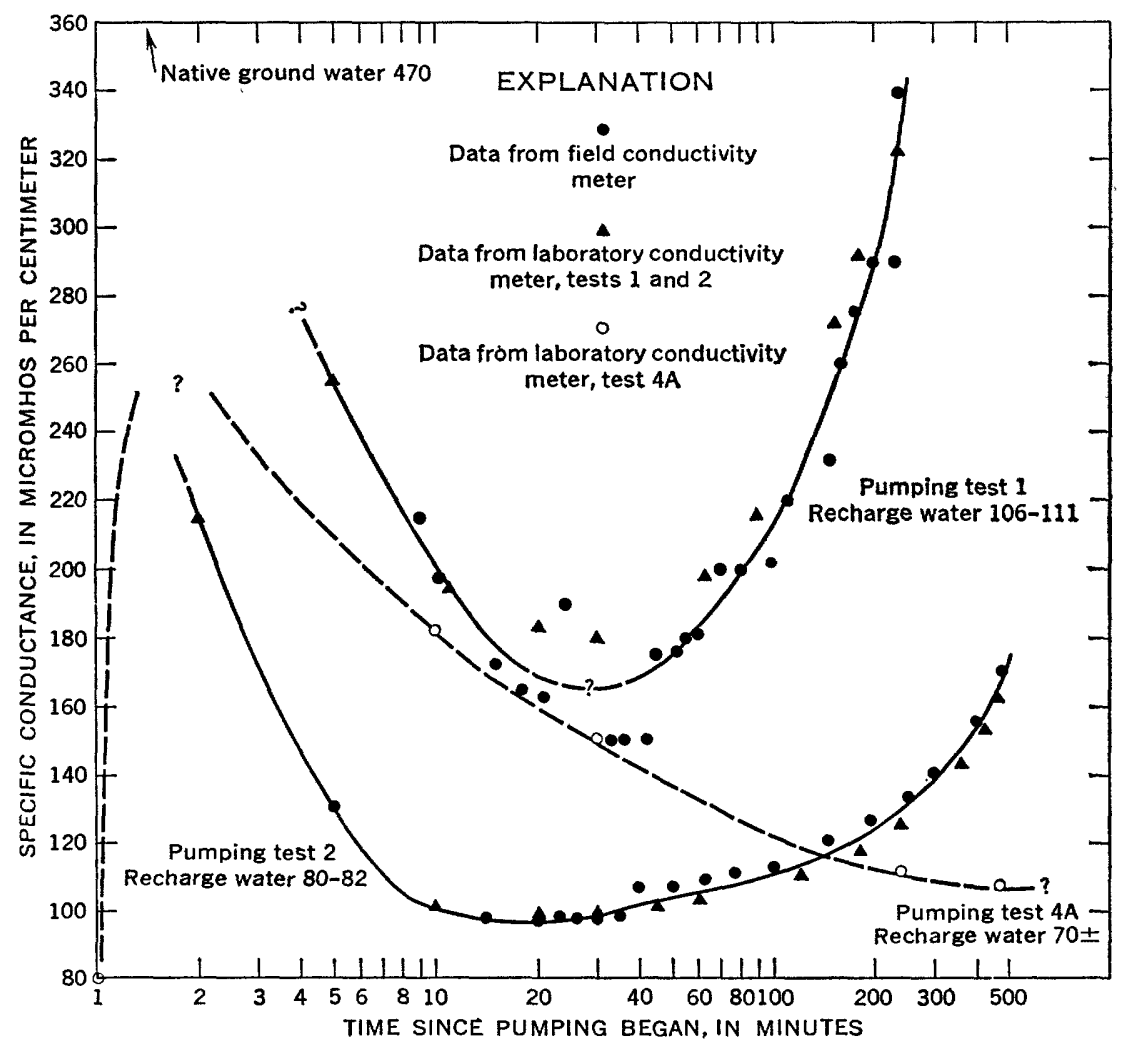

Figure 5.-Changes in specific conductance of water from the recharge well during pumping tests after artificial recharge.

The unexpectedly large proportion of native ground water in the water pumped during the early parts of the pumping tests indicates that the injected water neither mixed completely with the native ground water in the aquifer nor replaced the native ground water completely in an appreciable volume of the aquifer. The principal aquifer tapped by the recharge well is about $38 \mathrm{ft}$ thick and is highly permeable. (See p. E45.) The water injected was denser than the native ground water because it was substantially colder. The denser recharge water undoubtedly tended to remain in the lower part of the aquifer as it moved outward from the well, and apparently a layer of the warmer native ground water was left in the upper part of the aquifer. Stratification may have been favored by a vertical difference in permeability within the aquifer-the lower part may be more permeablebut such a difference is probably not a necessary condition. Mixing of the waters in the layers probably was retarded also by the substantial differences in their viscosities. Whatever the controlling phe- 


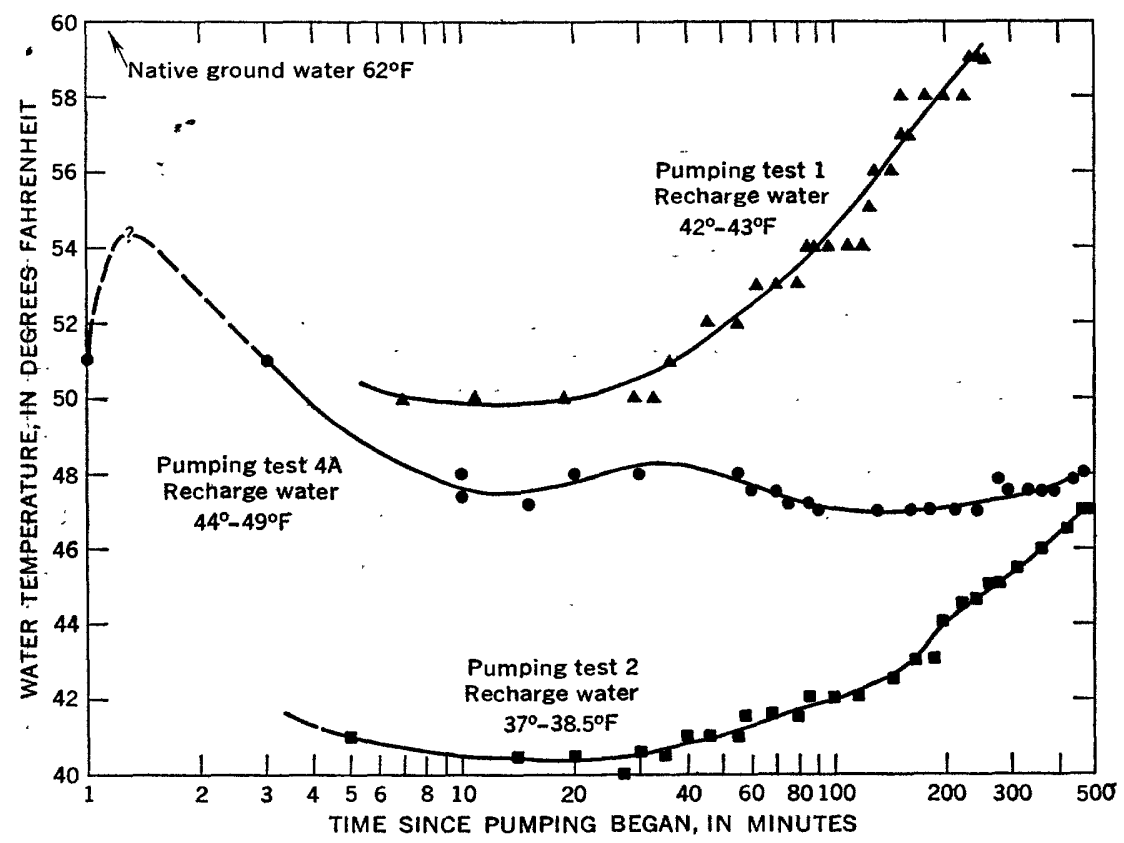

FigURE 6.-Changes in temperature of water from the recharge well during pumping tests after artificial recharge.

nomena, an appreciable amount of native ground water remained in the aquifer near the recharge well.

Thus, when pumping began, the mixture of water first withdrawn contained a large proportion of native ground water and it had an appreciably higher temperature and specific conductance than the water injected. For some time after pumping began, the native ground water continued to enter the well preferentially. The principal reason probably was that the warmer native ground water, due to its lesser viscosity, required a gentler hydraulic gradient to move it toward the well than would be required to move the cooler recharge water at the same rate.

As the warmer water was gradually removed from the vicinity of the well, the water being withdrawn included more and more of the recharge water, until it consisted largely of recharge water. This condition is indicated by the low points of the curves in figures 5 and 6 . As pumping continued and more of the recharge water was removed from the aquifer, the water being pumped gradually included again a greater proportion of native ground water, and the temperature and chemical character of the water pumped changed accordingly. 


\section{DISSOLVED OXYGEN}

Most of the dissolved oxygen that was present in the recharge water entering the well came out of solution or otherwise was removed before the water was pumped back to the land surface.

The marked reduction in dissolved-oxygen content is apparent from a comparison of the dissolved-oxygen contents in samples of the recharge water and of the water pumped from the recharge well during pumping tests (fig. 7 and table 4). As figure 7 shows, the dissolved-

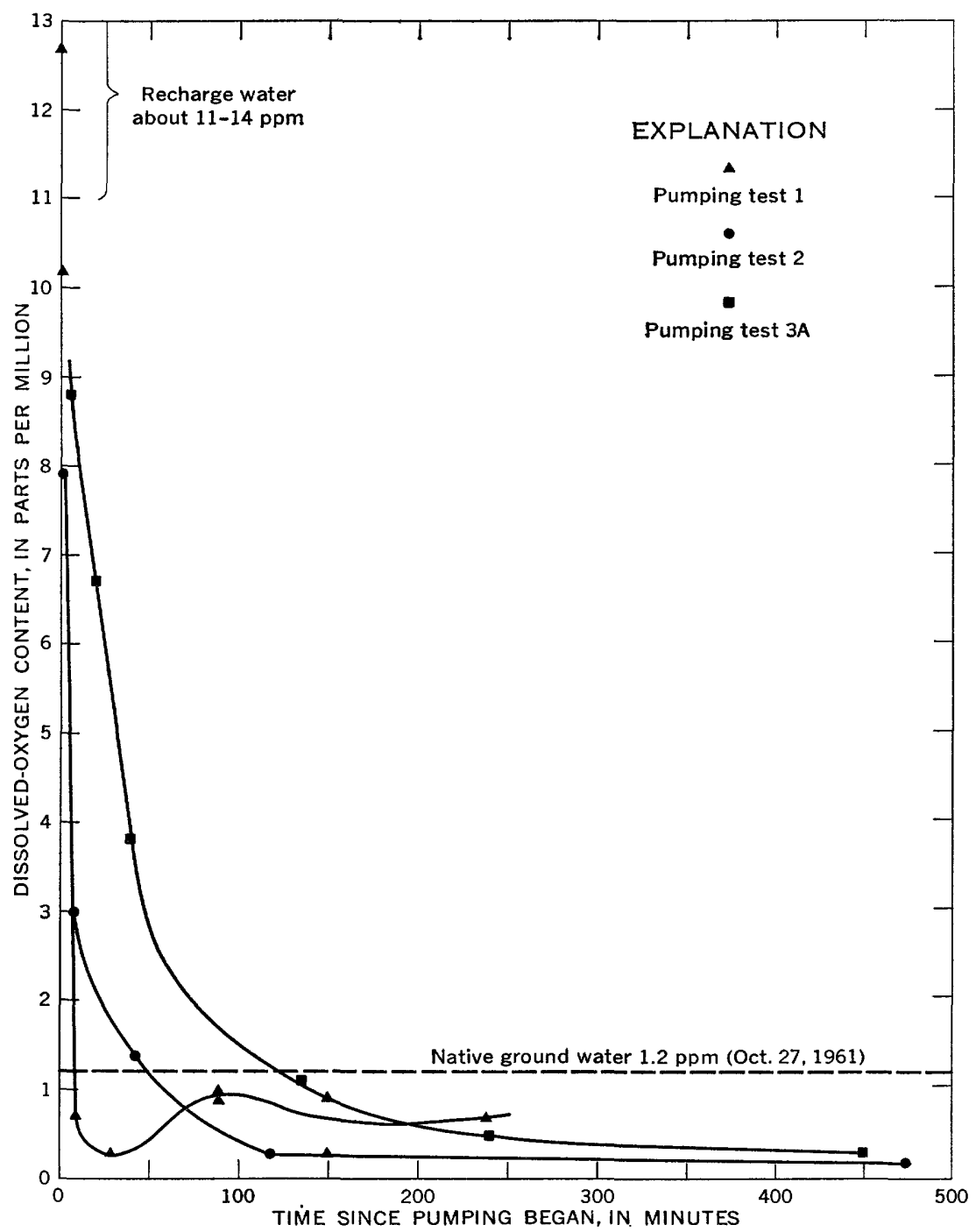

Figure 7.-Changes in dissolved-oxygen content of water from the recharge well in pumping tests after artificial recharge. 
oxygen content of the water pumped was initially near that in the recharge water (11-14 ppm) but declined to less than $1 \mathrm{ppm}$ very rapidly in test 1 and more slowly in the succeeding pumping tests that followed longer periods of recharge. Following its initial decline, the dissolved-oxygen content remained below $1 \mathrm{ppm}$, even during periods when the water pumped consisted mostly of recharge water. Thirty minutes after pumping began in pumping test 1 , the specific conductance (fig. 5) indicated that the water being pumped was about 80 percent recharge water. Thus, the dissolved-oxygen content, if none had been dissipated, should have been about $9 \mathrm{ppm}$ rather than the $0.3 \mathrm{ppm}$ determined from the sample collected at that time (fig. 7).

There are two possible explanations for the removal of dissolved oxygen from the recharge water: (1) Some of the oxygen could have entered into a chemical reaction in the aquifer, such as the oxidation of ferrous iron to the ferric state, or (2) the dissolved oxygen along with other gases could have come out of solution as air bubbles, either while in the aquifer or during recharge or pumping.

Because of the low content of dissolved iron both surface and ground water at The Dalles, precipitation of iron and any resultant depletion of dissolved oxygen by this means probably was insignificant, although at times the apparent iron content of the water pumped after recharge was more than twice that of either the recharge water of the native ground water. (See table 4.) A comparison of the chemical and sediment data shows that, when the sediment content increased, the iron content of the water from the well also increased. The water samples used for iron determination were not filtered prior to analysis; therefore, they contained representative amounts of this sediment. Because the sediment was made up largely of small particles of the basalt, which contains minor amounts of magnetite $\left(\mathrm{Fe}_{3} \mathrm{O}_{4}\right)$ as well as other iron minerals, and because the samples for iron determination were treated with concentrated hydrochloric acid, some of the iron in the sediment undoubtedly was dissolved during storage and analysis.

During pumping test $3 \mathrm{~A}$, after the period of recharge when the water injected presumably contained coagulating agents and precipitates, the initial sample had an iron content of $7.2 \mathrm{ppm}$ (table 4). Because this sample also contained a very large amount of sediment, most of that iron probably was dissolved from the sediment.

\section{EFFECTS ON THE AQUIFER AND THE RECHARGE WELL}

\section{BUILDUP OF WATER LEVELS}

The injection of water into the recharge well caused a corresponding rise in level in most of the five observation wells, especially during the 
longer periods of recharge ( $\mathrm{pl} .1$ ). The injection of water during recharge test 4 , which caused a maximum buildup of the level in the recharge well of $25 \mathrm{ft}$, caused a rise of as much as $1.5 \mathrm{ft}$ in well $3 \mathrm{E} 1$ (City Hall), about 1 foot in well 4C1 (Stadelman), at least $1 \mathrm{ft}$ in well 4E1 (I.O.O.F.), and nearly $1.5 \mathrm{ft}$ in well $4 \mathrm{P} 1$ (Marx). The recharge during that test apparently also caused some rise, probably amounting to less than $1 \mathrm{ft}$, in the level in well 8A1; however, the short-term trends of levels in that well are largely masked by fluctuations due to changes in air pressure. A response at well $8 \mathrm{~A} 1$ was unexpected because that well was thought to be outside the area of influence of the recharge tests.

The last two recharge tests were long enough so that responses not only to artificial recharge but also to regional natural recharge were indicated by the changes in the water levels in all wells. The response to the natural recharge did not, however, mask the dissipation of the ground-water mound (pl.1).

The buildup of the piezometric surface that resulted from the recharge was short lived; the recharge mound dissipated rapidly after each period of injection. After recharge test 1, of 8-hour duration, the level in the recharge well declined to the prerecharge static level within 56 minutes after recharge was stopped. Even after the fourth and longest recharge test, there was no evidence of residual buildup after 4 days. Apparently, the high permeability of the aquifers allowed the injected water to spread rapidly through such a large area that the effect on the piezometric surface soon was not measurable even at the recharge well.

\section{SPECIFIC CAPACITY}

One of the most important factors affecting the yield and drawdown of the recharge well was the decrease in effective permeability of the aquifer near the recharge well due to the injection of cold recharge water (p. E17). The reduction in specific capacity that is attributable to this temperature effect can be estimated by applying the temperature conversion factors of Wenzel $(1942$, p. 62). Inasmuch as formulas for determining the coefficient of permeability by discharging-well methods contain a factor equivalent to specific capacity-usually quantity, $Q$, divided by drawdown, $s$-the correction factors for temperature apply to changes in specific capacity to the same extent that they apply to the coefficient of permeability, provided that entrance lossesenergy losses due to friction and turbulence as the water enters and moves through the well-are negligible. In the range of temperatures of the water pumped from the recharge well during this study $\left(40^{\circ}-\right.$ $62^{\circ} \mathrm{F}$ ), a temperature change of $1^{\circ} \mathrm{F}$ causes a corresponding change in specific capacity of about 1.8 percent. 
The specific-capacity data in table 1 include unadjusted values based on the average rate of pumping or recharge during each test period and the drawdown or buildup of levels measured near the end of that period. Also shown are appropriate measurements of water temperature and theoretical values for specific capacities after adjustment to a water temperature of $60^{\circ} \mathrm{F}$. The specific-capacity values have not been corrected for possible effects of short-term changes in air pressure, effects of pumping of nearby wells, or for the differences in duration among the tests; however, any inaccuracy that may result from those influences is believed to be small and probably does not materially affect the relationships shown by the table.

Except for recharge test 2 and pumping test 2, the table indicates a general progressive decrease in specific capacity as more water was injected. All the recharge tests other than test 2 caused some reduction in specific capacity - that is, the pumping specific capacities after a period of recharge were somewhat less than before that recharge period. The reductions are believed to have been caused by partial clogging of the aquifer in the vicinity of the recharge well. The differences in the specific capacities, adjusted for temperature effect, before and after recharge presumably reflect the relative degrees of clogging. Thus, the first recharge test caused an apparent reduction in specific capacity of about $9 \mathrm{gpm}$ per $\mathrm{ft}$, or about 9 percent of the prerecharge value, after adjusting for temperature effects. This small reduction indicates that only a minor amount of clogging occurred. The fourth recharge test, however, because it contributed to an overall decrease of $32 \mathrm{gpm}$ per $\mathrm{ft}$, or 33 percent of the prerecharge value, evidently caused significant amount of clogging.

Except for the severe clogging by chemical floc during recharge test 3 , the clogging probably was caused chiefly by bubbles of air that came out of solution from the recharge water. This conclusion is supported by the decrease in dissolved-oxygen content of the recharge water after it entered the well (p. E33). Although some decrease in dissolved-gas content probably occurred during pumping as the water passed through the turbine impellers, the fact that some of the pumped water contained nearly as much dissolved oxygen as the recharge water (fig. 7) proved that the pumping process was not the major cause of the decrease. Also, during all the recharge tests, crackling sounds, believed to have been caused by air coming out of solution in the form of bubbles, could be heard at several points along the pipeline to the well. By far the greatest local reduction of pressure on the water moving into the well occurred as the water passed through the turbine impellers, where air must have also come out of solution. Even though the relatively greater pressure in the well (p. E19) would tend 
to force the air back into solution, the recharge water very likely contained a stream of air bubbles as it left the pump and carried at least part of those bubbles into the aquifer.

Most of the time, other possible causes of the clogging are believed to have been less important. These include chemical precipitations within the aquifer and sediment in the recharge water. Except for possible precipitation of aluminum hydroxide during the third recharge test, the chemical reactions that occurred withn the aquifer probably did not result in precipitates that would cause appreciable clogging.

Nearly all the sediment introduced into the well with the recharge water probably was removed during the pumping tests. Thus, residual sediment from the earlier recharge tests should not have been a major reason for the decrease in specific capacity as measured during the later tests. During the latter parts of most pumping tests, the sediment content of the water was at or near zero or consisted almost entirely of small grains of aquifer materials which likely had been loosened during previous surging. Moreover, the last two surging operations, which totaled more than 3 hours, probably removed most of the sediment that remained in the aquifer until then.

Table 1 shows that low specific capacities of the recharge well, determined from the pumping tests immediately after the third and fourth periods of recharge, were substantially improved by subsequent pumping and surging. After each of the last two recharge periods, the increase in specific capacity due to the pumping and surging is also indicated by the progressively shallower pumping levels shown on plate 1-points labeled " $a$ " during the months of February, April, and May, 1961. The differences in the pumping levels after each of these recharge periods indicate roughly the improvements in specific capacity, inasmuch as the pumping rates during all these tests differed by only about $100 \mathrm{gpm}$.

The greatest increase in specific capacity-about $23 \mathrm{gpm}$ per $\mathrm{ft}$, adjusted for temperature effects-was caused by the surging and pumping on May 4, 1961. That increase was reflected in the pumping level ( $\mathrm{pl} .1$ ), which was about $10 \mathrm{ft}$ higher than that during the previous pumping test, on April 24.

\section{RECOVERY OF INJECTED WATER}

During the pumping tests and surging operations following the four periods of recharge, about 6.2 million gallons of water were removed from the recharge well. This figure is partly estimated because during surging nearly all the water withdrawn from the well bypassed the discharge meter. Although the time of pumping during the surging 
operations is known approximately, the yield of the well during those times can only be estimated by multiplying the specific capacity by the drawdown during the periods of bypass.

Determinations of specific conductance of the water pumped from the well following the four periods of recharge show that more than 85 percent of the water withdrawn was recharge water. (See p. E30.)

\section{CONDITION OF PUMPING EQUIPMENT}

The injection of water through the pump in the recharge well apparently caused no damage or excessive wear to the pumping equipment. The pump was removed from the well on May 23, 1961, and carefully checked by the Pump Pipe \& Power Co., Portland, Oreg. According to Cecil Garbe of that firm, there was no damage or excessive wear that could be attributed to the recharge or surging operations.

\section{METHODS AND TECHNIQUES FOR FURTHER ARTIFICIAL RECHARGE}

The results of the present study suggest certain important considerations in the design of a system for subsurface injection and techniques that would enhance the chances of success in any artificialrecharge operations of this type.

No serious problems are foreseen in connection with additional artificial recharge through the Jordan Street well. The recharge operations already completed caused little, if any, permanent decrease in the water-yielding capacity of the well or aquifer materials and caused no apparent damage to the pumping equipment. However, the use of a well and piping system designed especially for injection probably would allow the greatest flexibility of recharge operations and the establishment of conditions even more favorable for long-term injection.

With any system for subsurface injection, every effort should be made to prevent the entrainment of air and to keep in solution any air that is already dissolved in the recharge water. To this end, the recharge water should be injected into the well in a full pipe under pressure and not allowed to enter by free fall. During the recharge tests previously described, this condition was achieved by injecting the water through the impellers of the pump; the restriction of flow there was sufficiently great that a large pressure drop was created in that section. If injection is through a separate pipe or pipes, adequate back pressure can be produced by means of a fixed nozzle (reducer) or a controllable valve at the lower end of the injection pipe. At other 
points in the pipeline conveying the recharge water, sharp pressure reductions should be prevented where possible.

A recharge well should be considered as a piece of equipment which probably will require periodic maintenance and repair, as by cleaning or redevelopment, and eventually may need to be replaced. The information obtained from the relatively short recharge experiments that were conducted during this study is insufficient for the accurate prediction of the useful life of a recharge well in the Dalles area. Even under the best conditions the need for flushing by pumping or surging might occur sufficiently often so that a permanent pump may be needed in the recharge well.

The substantial decrease in the specific capacity of the recharge well caused by the accidental introduction of aluminum hydroxide floc and the large amount of sediment pumped from the well thereafter indicate the need for strict control of the quality of the water entering a recharge well.

In the planning and design for artificial recharge through wells, the importance of adequate background information cannot be overemphasized. Such information should include (1) an understanding of the ground-water system to be recharged and how the system functions, (2) knowledge of the chemical and physical character and biotic content of the recharge water and the native ground water, and (3) a recognition of the possible problems and risks associated with artificial recharge.

Similarly, various operational data are need to evaluate the results of artificial recharge through wells. These data include, as a minimum, (1) records of the volumes and rates of water injection and withdrawal, (2) the type, amounts, and times of water treatment, (3) fluctuations of ground-water levels, and (4) periodic determinations of the character and changes in character of the recharge and ground waters.

\section{CONCLUSIONS}

The major conclusions resulting from this study are as follows:

1. A total of 81.4 million gallons ( 250 acre- $\mathrm{ft}$ ) of stream water from the Dalles system was injected into well $4 \mathrm{~F} 1$ during a total recharge time of 900 hours, at an average rate of about 1,500 gpm (2.2 million gallons per day). If water could be injected into the well at that rate for a total of 180 days from October to April, when water in excess of the city's demand is normally available in the Mill Creek system, the total recharge would amount to 390 million gallons, or about 1,200 acre-ft per year.

2. The physical and hydraulic properties of the aquifers, the arrangement of the Dalles supply system, and the quality of the city's 
surface-water supply are favorable for artificial recharge of the confined basalt aquifers in the area by injection of city water through wells. Because the aquifer materials are highly permeable, they conducted the water rapidly away from the recharge well and are less subject to clogging than would be materials having smaller pore spaces. The moderately high pressure under which the water system operates allowed injection at a rapid rate and prevented the entrainment of air in the water entering the well. The amount of sediment in the city water normally was too small to cause serious clogging of the aquifers, and the city water mixed with the native ground water without apparent undesirable chemical effects.

3. The artificial recharge had no serious deleterious effects on the quality of the ground water. The sediment that was injected was almost entirely removed from the recharge well during subsequent pumping and surging, largely during times when the well water was being bypassed into the storm sewer. The principal chemical and physical effects of the water were a lowering of the dissolvedsolids content to less than that of the native ground water and a lowering of the temperature. There was no deterioration of the bacteriological purity of the ground water.

4. The injection of the recharge water through the existing pump had no damaging effects upon the pumping equipment. The tests did not determine, however, whether injection of water through the pump for a much longer period of time would eventually cause undue wear or other damage.

5. Injection during each of the recharge periods caused some decrease in the specific capacity of the recharge well. The principal causes for these decreases were (1) the greater viscosity of the colder recharge water, (2) partial clogging of the aquifer materials in the vicinity of the well by bubbles of air that came out of solution, and (3) in one case, clogging by a chemical floc that was present in the recharge water. The decrease in specific capacity due to the lower temperature was considered to be temporary; it doubtless gradually lessened and disappeared entirely as the residual recharge water warmed to the temperature of the native ground water. The clogging agents were removed satisfactorily by surging and pumping.

6. The mound of artesian pressure that was built up during periods of artificial recharge dissipated rapidly, and no residual buildup was measurable even in the vicinity of the recharge well within a few days after the recharge had stopped. The rapid dissipation of the recharge mound suggests that the water added by this 
type of artificial recharge would spread widely in the area, rather than remaining in the vicinity of the recharge wells. However, the geologic and hydrologic conditions in the Dalles ground-water area preclude the escape of the injected water from the area by subsurface migration.

None of the recharge tests was long enough to indicate the amount of buildup of regional levels that might be achieved during long-term injection. Although the estimated amount of surplus treated city water is less than 10 percent of the estimated annual pumpage, it might be equivalent to a significantly greater proportion of the overdraft on the ground-water system-the difference between discharge and natural recharge. Therefore, the injection of that amount of water into the principal artesian aquifers, if successful for prolonged periods, might slow the currently drastic year-to-year decline of ground-water levels.

7. No serious problem can be foreseen in connection with additional subsurface injection using the treated city water, either through the Jordon Street well or a separate well and injection system of adequate design. However, the data and experience gained during this study do not completely eliminate the possibility that some unforeseen problem may arise during longer periods of recharge.

8. The substantial decrease in the specific capacity of the recharge well caused by the introduction of aluminum hydroxide floc during one test and the large amount of sediment pumped from the well thereafter indicate the need for strict control of the quality of water entering an injection well.

9. Adequate background information and operational data are essential for effective planning, operation, and evaluation of artificial recharge through wells. The necessary background data include (1) an understanding of the ground-water system to be recharged and how the system functions, (2) knowledge of the chemical and physical character and biotic content of the recharge water and the native ground water, and (3) a recognition of the possible problems and risks associated with artificial recharge. The minimum operational data include (1) records of the volumes and rates of water injection and withdrawal, (2) the type, amounts, and times of water treatment, (3) fluctuations of ground-water levels, and (4) periodic determinations of the character and changes in character of the recharge and ground waters. 


\section{REFERENCES}

American Water Works Association, 1950, Water quality and treatment, a manual [2d ed.] : New York, Am. Water Works Assoc., 451 p., 96 figs.

Engler, Kyle, Bayley, F. H., 3d, and Sniegocki, R. T., 1963, Studies of artificial recharge in the Grand Prairie region, Arkansas-environment and history: U.S. Geol. Survey Water-Supply Paper 1615-A, 32 p., 4 pls., 7 figs.

Hem, J. D., 1959, Study and interpretation of the chemical characteristics of natural water: U.S. Geol. Survey Water-Supply Paper 1473, 269 p., 2 pls., 40 figs.

Orlob, G. T., and Radhakrishna, G. N., 1958, The effects of entrapped gases on the hydraulic characteristics of porous media: Am. Geophys. Union Trans., v. 39, no. 4, p. 648-659, 10 figs.

Piper, A. M., 1932, Geology and ground-water resources of the Dalles region, Oregon: U.S. Geol. Survey Water-Supply Paper 659-B, p. 107-189, pls. 11-19, figs. 30-32.

Price, C. E., 1961, Artificial recharge through a well tapping basalt aquifers, Walla Walla area, Washington: U.S. Geol. Survey Water-Supply Paper 1594-A, 33 p., 4 figs.

Sniegocki, R. T., 1960, Ground water recharge and conservation-effects of viscosity and temperature: Am. Water Works Assoc. Jour., v. 52, no. 12, p. 1487-1490, 3 figs.

- 1963, Geochemical aspects of artificial recharge in the Grand Prairie region, Arkansas: U.S. Geol. Survey Water-Supply Paper 1615-E, 41 p., 1 pl., 7 figs.

1963, Problems in artificial recharge through wells in the Grand Prairie region, Arkansas: U.S. Geol. Survey Water-Supply Paper 1615-F, 25 p., 1 pl., 10 figs.

1964, Hydrogeology of a part of the Grand Prairie region, Arkansas: U.S. Geol. Survey Water-Supply Paper 1615-B, 72 p., 8 pls., 17 figs.

Sniegocki, R. T., Bayley, F. H., 3d, and Engler, Kyle, 1963, Equipment and controls used in studies of artificial recharge in the Grand Prairie region, Arkansas: U.S. Geol. Survey Water-Supply Paper 1615-C, 39 p., 25 figs.

Sniegocki, R. T., Bayley, F. H., 3d, Engler, Kyle, and Stephens, J. W., 1965, Testing procedures and results of studies of artificial recharge in the Grand Prairie region, Arkansas: U.S. Geol. Survey Water-Supply Paper 1615-G, 56 p., 25 figs.

Sniegocki, R. T., and Reed, J. E., 1963, Principles of siphons with respect to artificial-recharge studies in the Grand Prairie region, Arkansas: U.S. Geol. Survey Water-Supply Paper 1615-D, 19 p., 9 figs.

Theis, C. V., 1935, The relation between the lowering of the piezometric surface and the rate and duration of discharge of a well using ground-water storage : Am. Geophys. Union Trans., v. 16, p. 519-524.

Wenzel, L. K., 1942, Methods for determining permeability of water-bearing materials: U.S. Geol. Survey Water-Supply Paper 887, 192 p., 6 pls., 17 figs. 
TABLES 2-5 



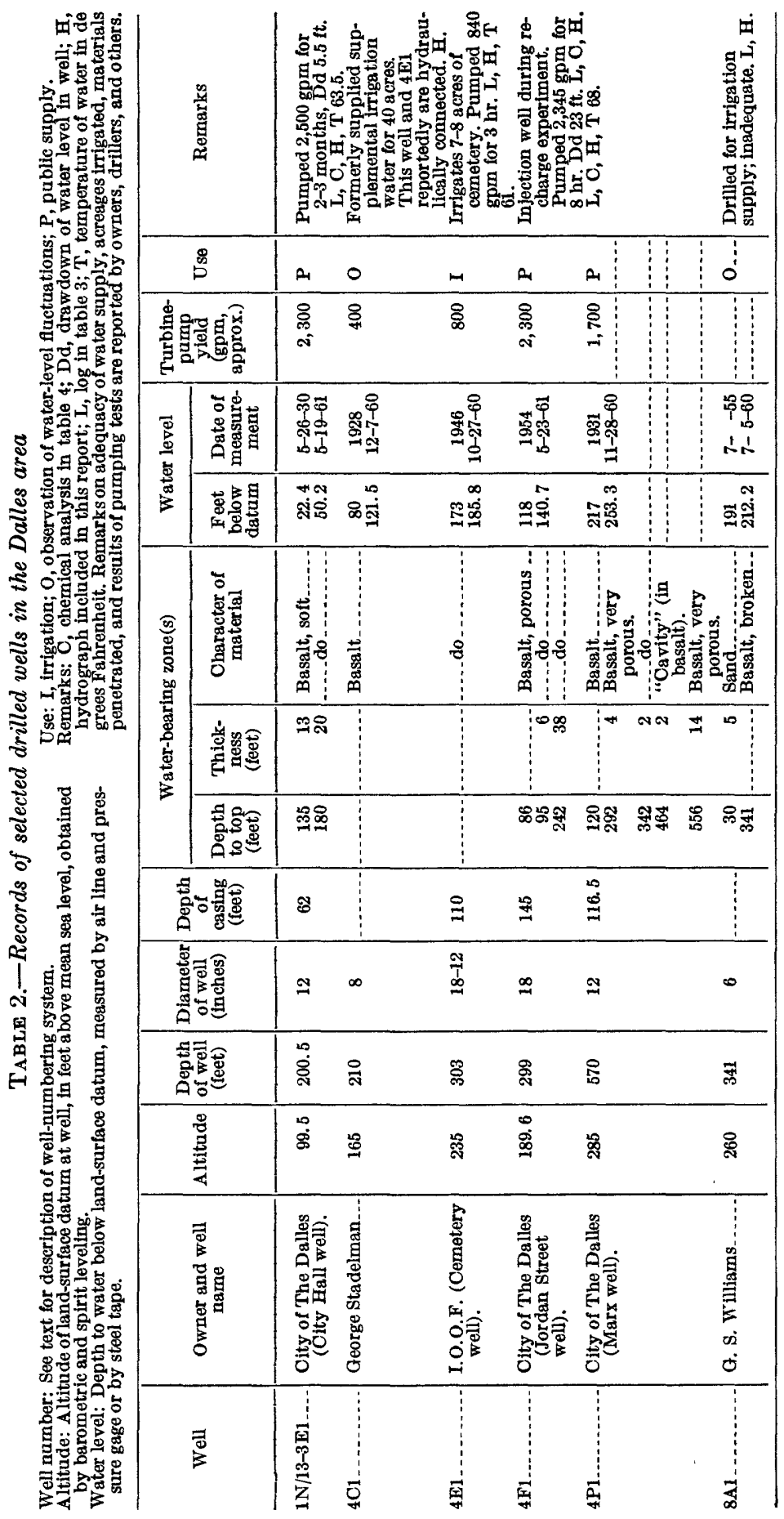




\section{TABLE 3.-Drillers' logs of wells}

[Drillers' designations edited for consistency of presentation, but otherwise unchanged. Stratigraphic"and parenthetical designations by B. L. Foxworthy. Depths are in feet below land surface at well]

\begin{tabular}{|c|c|c|c|c|c|}
\hline Materials & $\begin{array}{c}\text { Thick- } \\
\text { ness } \\
\text { (ft) }\end{array}$ & $\begin{array}{l}\text { Depth } \\
\text { (ft) }\end{array}$ & Materials & $\begin{array}{l}\text { Thick- } \\
\text { ness } \\
\text { (ft) }\end{array}$ & $\underset{\text { (ft) }}{\text { Depth }}$ \\
\hline
\end{tabular}

1N/13-3 E1

[City of The Dalles (City Hall well). Alt $99.5 \mathrm{ft}$. Drilled by G. E. Scott,1923]

\begin{tabular}{|c|c|c|c|c|c|}
\hline $\begin{array}{l}\text { Soil: } \\
\text { Clay } \\
\text { Columbia River Group: } \\
\text { Stone, shelly } \\
\text { Rock, black. } \\
\text { Clay, blue (weath- } \\
\text { ered basalt?) } \\
\text { Rock, black } \\
\text { Stone, gray, hard } \\
\text { Rock, black, hard.-. }\end{array}$ & $\begin{array}{r}12 \\
7 \\
11 \\
31 \\
1 \\
4 \\
26\end{array}$ & $\begin{array}{l}61 \\
62 \\
66 \\
92\end{array}$ & $\begin{array}{l}\text { Columbia River } \\
\text { Group-Continued } \\
\text { Stone, gray, very } \\
\text { hard--.-- } \\
\text { Rock, black, soft, } \\
\text { water-bearing } \\
\text { Rock, black, solid, } \\
\text { very hard.-.-. } \\
\text { Rock, black, soft, } \\
\text { water-bearing...- }\end{array}$ & $\begin{array}{l}43 \\
13 \\
32 \\
20.5\end{array}$ & $\begin{array}{l}135 \\
148 \\
180 \\
200.5\end{array}$ \\
\hline
\end{tabular}

1N/13-4E1

[I.O.o.F. Cemetery. Alt 235 ft. Drilled by Bert Clayton, 1946]

\begin{tabular}{|c|c|c|c|c|c|}
\hline 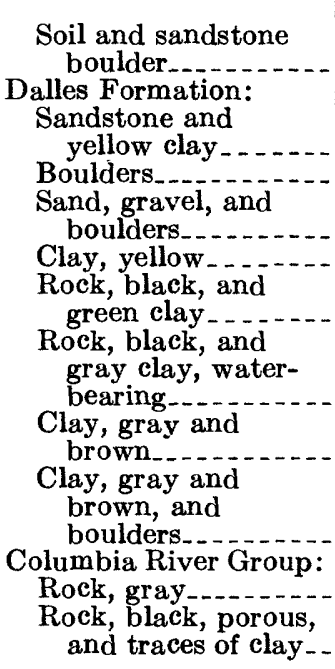 & $\begin{array}{r}22 \\
2 \\
18 \\
4\end{array}$ & $\begin{array}{l}25 \\
27 \\
45 \\
49 \\
\\
82\end{array}$ & 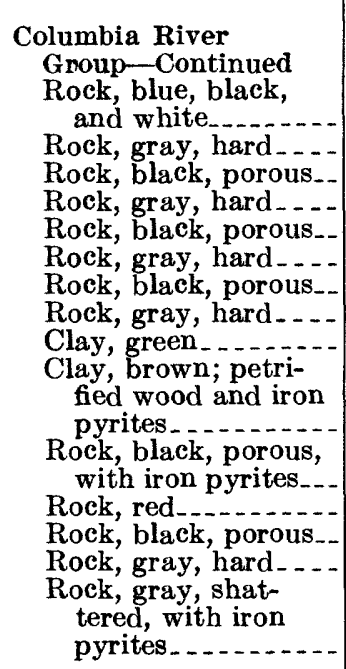 & $\begin{array}{r}25 \\
3 \\
6 \\
2 \\
8 \\
1 \\
26 \\
1 \\
26\end{array}$ & $\begin{array}{l}170 \\
173 \\
179 \\
181 \\
189 \\
190 \\
216 \\
217 \\
243 \\
\\
252 \\
263 \\
274 \\
281 \\
300 \\
\end{array}$ \\
\hline
\end{tabular}

IN/13-4F1

[City of The Dalles (Jordan Street well). Alt. 189.6 ft. Drilled by R. J. Strasser Drilling Co., 1954]

\begin{tabular}{|c|c|c|c|c|c|}
\hline $\begin{array}{l}\text { Slope wash and artifi- } \\
\text { cial fill: } \\
\text { Soil and sand_... } \\
\text { Columbia River } \\
\text { Group: } \\
\text { Boulders, basalt, } \\
\text { and sand......... }\end{array}$ & 16 & 16 & $\begin{array}{l}\text { Columbia River } \\
\text { Group-Continued } \\
\text { Basalt, gray, hard, } \\
\text { broken } \\
\text { Rock, black, porous; } \\
\text { brown clay in } \\
\text { seams... }\end{array}$ & 11 & $\begin{array}{l}35 \\
44\end{array}$ \\
\hline
\end{tabular}


RECHARGE OF BASALT AQUIFERS, THE DALLES, OREGON E47

TABLE 3.-Drillers' logs of wells-Continued

\begin{tabular}{|c|c|c|c|c|c|}
\hline Materials & $\begin{array}{l}\text { Thick- } \\
\text { ness } \\
\text { (ft) }\end{array}$ & $\begin{array}{c}\text { Depth } \\
\text { (ft) }\end{array}$ & Materials & $\begin{array}{c}\text { Thick- } \\
\text { ness } \\
\text { (ft) }\end{array}$ & $\begin{array}{c}\text { Depth } \\
\text { (ft) }\end{array}$ \\
\hline \multicolumn{6}{|c|}{ 1N $/ 13-4 F 1-$ Continued } \\
\hline 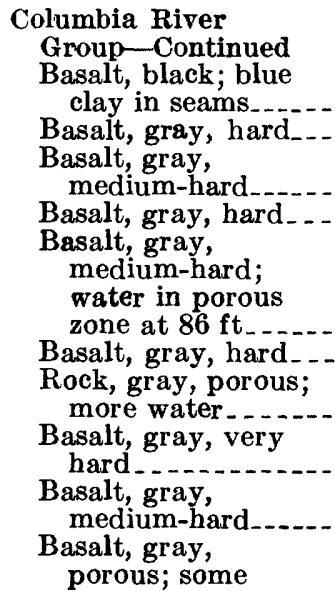 & $\begin{array}{r}10 \\
4 \\
6 \\
9 \\
2\end{array}$ & $\begin{array}{r}91 \\
95 \\
\\
101 \\
110 \\
112\end{array}$ & $\begin{array}{l}\text { Columbia River } \\
\text { Group-Continued } \\
\text { blue clay in } \\
\text { seams and hard } \\
\text { streaks 4-6 in. } \\
\text { thick in lenses } \\
2-4 \mathrm{ft} \text { apart } \\
\text { Basalt, gray } \\
\text { Rock, brown } \\
\text { Rock, gray, hard. } \\
\text { Rock, black, } \\
\text { porous; some } \\
\text { water } \\
\text { Basalt, black, } \\
\text { water-bearing } \\
\text { Basalt, gray, } \\
\text { medium-hard..... } \\
\text { Basalt, gray, } \\
\text { broken, caving.-. }\end{array}$ & $\begin{array}{r}37 \\
25 \\
5 \\
63 \\
\\
2 \\
36 \\
11 \\
\\
8\end{array}$ & $\begin{array}{l}149 \\
174 \\
179 \\
242 \\
\\
244 \\
\\
280 \\
291 \\
299\end{array}$ \\
\hline
\end{tabular}


TaBLE 3.-Drillers' logs of wells-Continued

\begin{tabular}{|c|c|c|c|c|c|}
\hline Materials & $\begin{array}{c}\text { Thick- } \\
\text { ness } \\
\text { (ft) }\end{array}$ & Depth & Materials & $\begin{array}{c}\text { Thick- } \\
\text { ness } \\
\text { (ft) }\end{array}$ & $\underset{\text { (ft) }}{\text { Depth }}$ \\
\hline
\end{tabular}

1N/13-4PI

[City of The Dalles (Marx well). Alt $285 \mathrm{ft}$. Drilled by Bennett (to $116.5 \mathrm{ft}$ ), and H. H. Wilburn and Son, 1931]

\begin{tabular}{|c|c|c|c|c|c|}
\hline 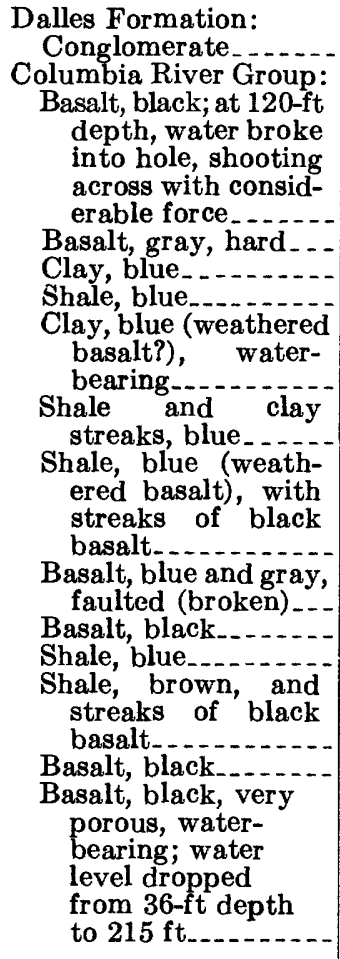 & $\begin{array}{l}14 \\
36 \\
11 \\
19 \\
\\
10 \\
26\end{array}$ & $\begin{array}{l}190 \\
\\
226 \\
237 \\
256 \\
\\
\\
266 \\
292\end{array}$ & 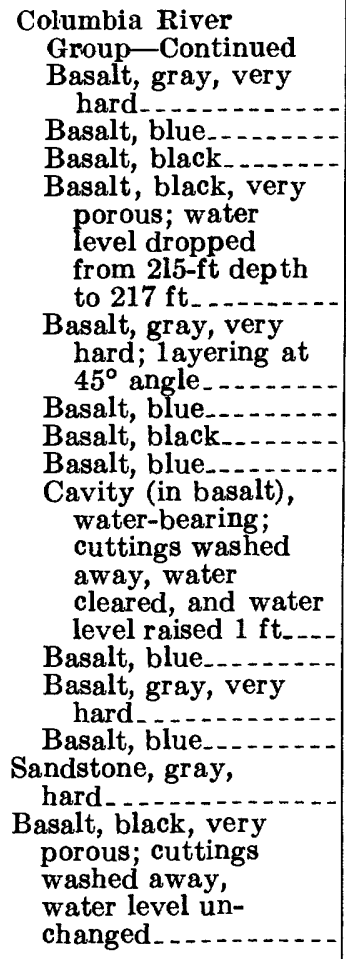 & $\begin{array}{r}2 \\
8 \\
6 \\
16 \\
60\end{array}$ & $\begin{array}{l}344 \\
400 \\
427 \\
445 \\
464\end{array}$ \\
\hline
\end{tabular}


RECHARGE OF BASALT AQUIFERS, THE DALLES, OREGON E49

TABLE 3.-Drillers' logs of wells-Continued

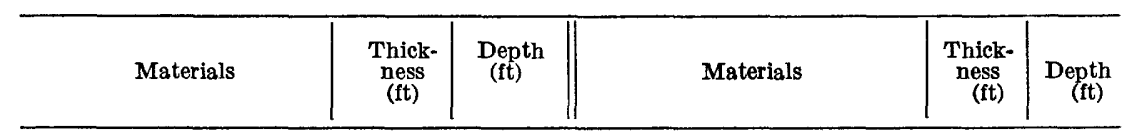

1N/13-8A1

[G. S. Williams. Alt $260 \mathrm{ft}$. Drilled in 1955]

\begin{tabular}{|c|c|c|c|c|c|}
\hline $\begin{array}{l}\text { Slope wash and } \\
\text { alluvium: } \\
\text { Sand and gravel } \\
\text { Rocks and boulders.- } \\
\text { Dalles (?) Formation: } \\
\text { Sand, water-bearing-- } \\
\text { Sand and shale...-.- }\end{array}$ & $\begin{array}{r}20 \\
10 \\
5 \\
5\end{array}$ & $\begin{array}{l}20 \\
30 \\
\\
35 \\
50\end{array}$ & $\begin{array}{l}\text { Columbia River } \\
\text { Group: } \\
\text { Clay and layers of } \\
\text { rock } \\
\text { Clay and hard basalt_- } \\
\text { Basalt, broken, } \\
\text { water-bearing (?) }\end{array}$ & $\begin{array}{r}222 \\
69\end{array}$ & $\begin{array}{l}272 \\
341\end{array}$ \\
\hline
\end{tabular}


TABLE 4.-Chemical analyses of

[Results in parts per million except as noted. Turbidity measured on Jackson candle turbidimeter. Samples except as

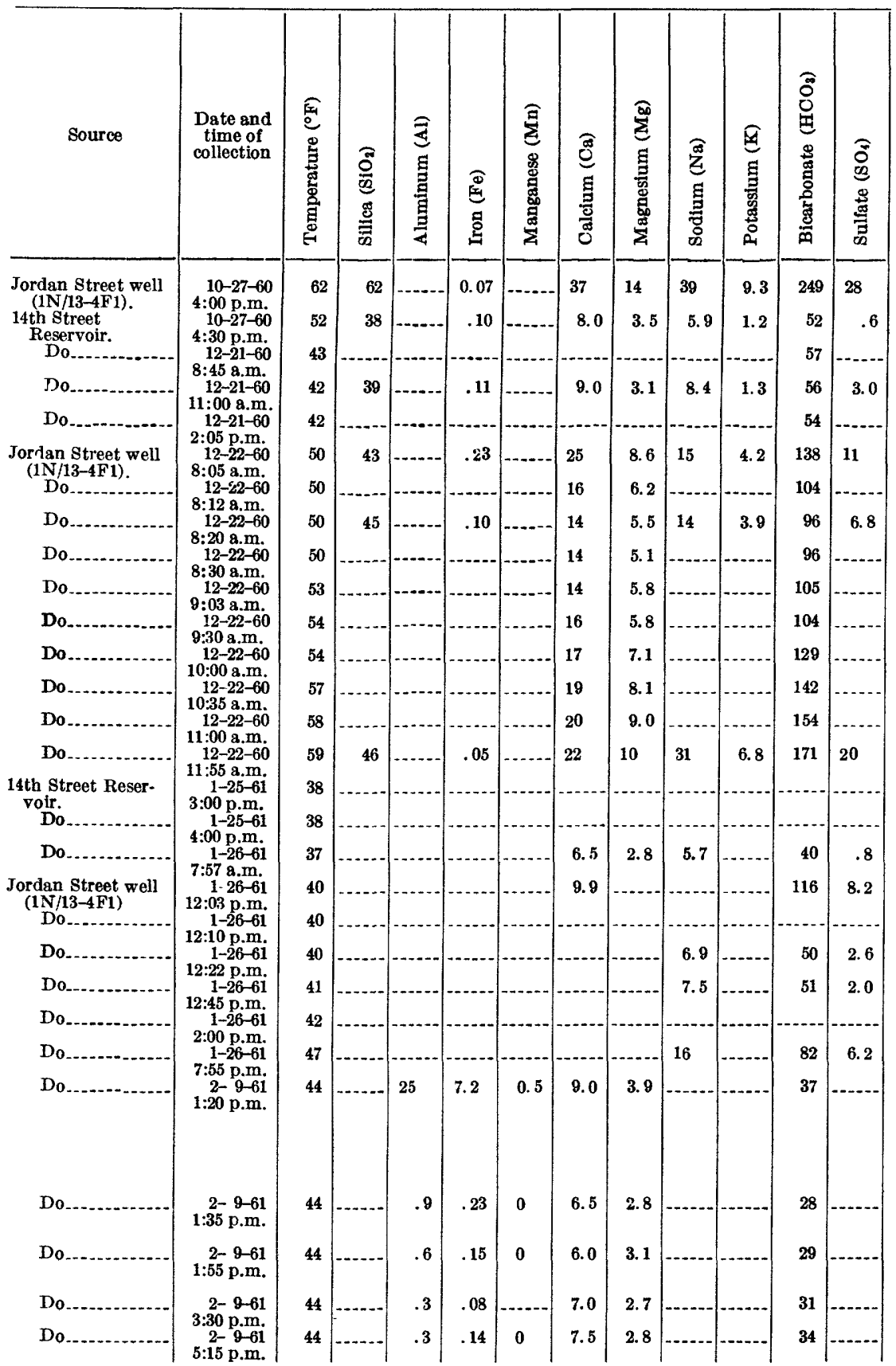




\section{waters from the Dalles area}

from well 1N/13-4F1 collected at sampling tap at pump except as noted. Analyses by the U.S. Geol. Survey noted]

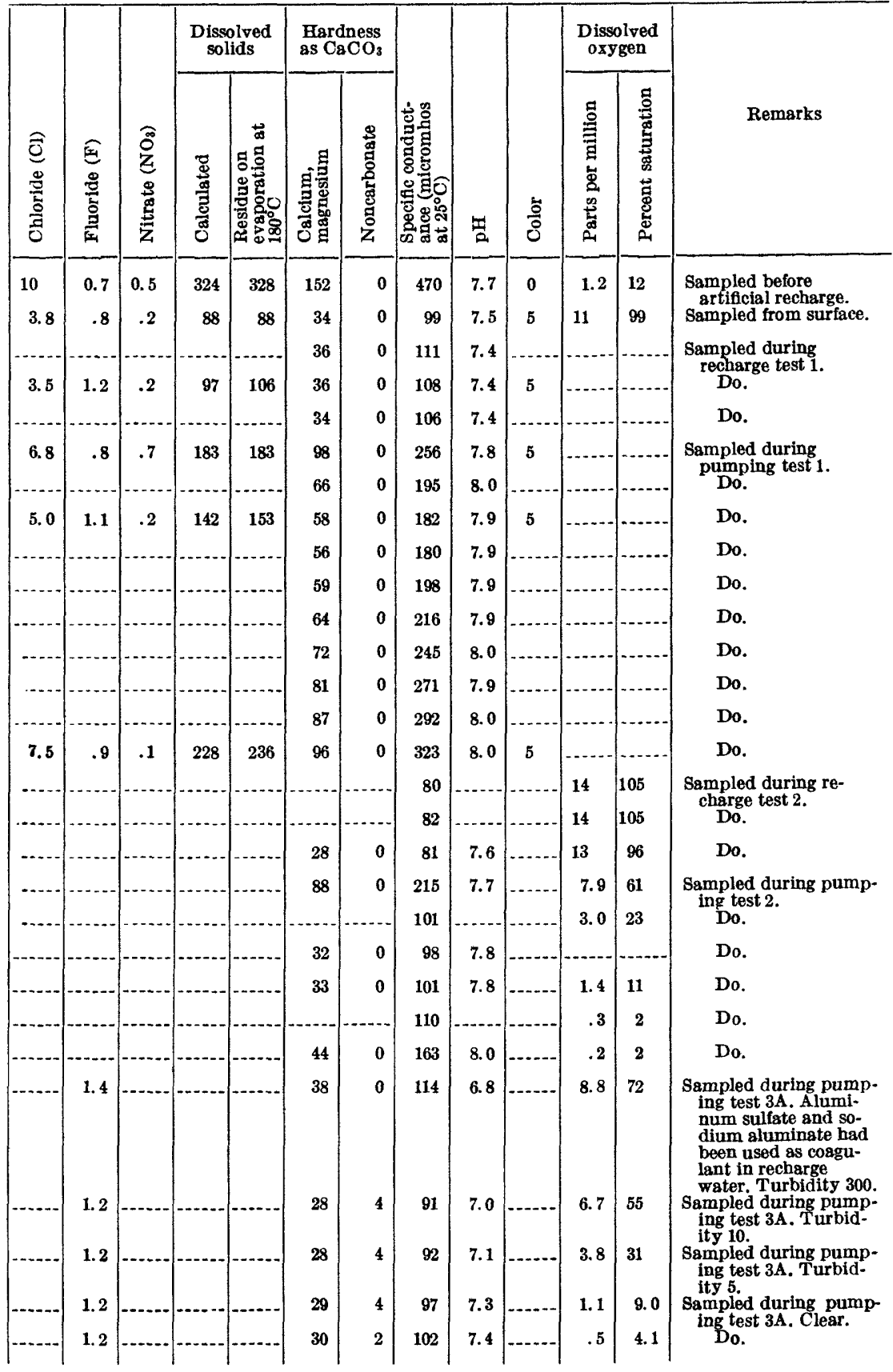


TABLE 4.-Chemical analyses of waters

\begin{tabular}{|c|c|c|c|c|c|c|c|c|c|c|c|c|}
\hline Source & $\begin{array}{l}\text { Date and } \\
\text { time of } \\
\text { collection }\end{array}$ & 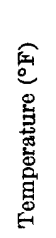 & 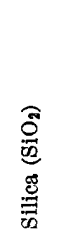 & $\begin{array}{l}\text { 离 } \\
\text { 慁 } \\
\text { 总 } \\
\text { 娄 }\end{array}$ & 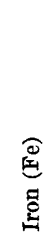 & 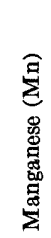 & 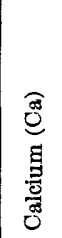 & 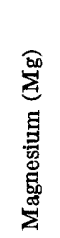 & 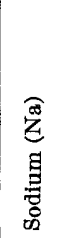 & 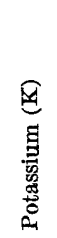 & 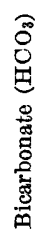 & 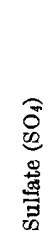 \\
\hline $\begin{array}{l}\text { Jordan Street well } \\
\text { (1N/13-4F1). } \\
\text { 14th Street Reser- } \\
\text { voir. } \\
\text { Do. }\end{array}$ & $\begin{array}{r}2-9-61 \\
8: 45 \text { p.m. } \\
4-21-61 \\
3: 55 \text { p.m. } \\
\text { 4-22-61 }\end{array}$ & $\begin{array}{l}45 \\
44 \\
44\end{array}$ & & .3 & $\begin{array}{l}.09 \\
.06\end{array}$ & $\ldots$ & 8.0 & 3.3 & & $\cdots$ & $\begin{array}{l}42 \\
34 \\
32\end{array}$ & \\
\hline $\begin{array}{l}\text { Jordan Street well } \\
\text { (1N/13-4F1). } \\
\text { Do }\end{array}$ & $\begin{array}{l}\text { 8:10 a.m. } \\
4-24-61 \\
3: 32 \text { p.m. } \\
4-24-61\end{array}$ & $\begin{array}{l}51 \\
48\end{array}$ & & .4 & .15 & & & & & - & $\begin{array}{l}33 \\
90\end{array}$ & \\
\hline Do & $\begin{array}{l}\text { 3:40 p.m. } \\
\text { 4-24-61 } \\
\text { 4:00 p.m. }\end{array}$ & 48 & $\cdots$ & .2 & .21 & & & & & & 74 & \\
\hline Do... & $4-24-61$ & 47 & & - & & & & & & & 52 & \\
\hline Do & $\begin{array}{l}7: 30 \text { p.m. } \\
4-24-61 \\
11.15 n-m\end{array}$ & 48 & & .3 & .19 & & & $\ldots$ & & & 51 & \\
\hline $\begin{array}{l}\text { Columbia River at } \\
\text { the Dalles Dam. } \\
\text { City Hall well }\end{array}$ & $\begin{array}{r}9-30-60 \\
10: 10 a . m . \\
7-26-30\end{array}$ & 66 & 10 & 0 & $\begin{array}{l}.03 \\
.02\end{array}$ & 0 & $\begin{array}{l}23 \\
18\end{array}$ & $\begin{array}{l}5.4 \\
8.2\end{array}$ & 11 & 1.5 & 196 & 19 \\
\hline $\begin{array}{l}\text { (NN/13-3E1). } \\
\text { Do }\end{array}$ & $1-29-51$ & & & 1.2 & 0.06 & & & & & & 171 & 29 \\
\hline Marx well & $3-16-51$ & & & .2 & .09 & & & & & & 158 & 23 \\
\hline Do & $7-30-58$ & 68 & 74 & 0 & .06 & 0 & 17 & 6.8 & 44 & 8.0 & 190 & 10 \\
\hline $\begin{array}{l}\text { Do } \\
\text { Mill Creek } \\
\text { (at Wicks treat- } \\
\text { nent plant). }\end{array}$ & $\begin{array}{l}6-22-61 \\
3-6-56\end{array}$ & 68 & $\begin{array}{l}66 \\
38\end{array}$ & .6 & $\begin{array}{l}.04 \\
.41\end{array}$ & 0 & $\begin{array}{l}26 \\
4.8\end{array}$ & $\begin{array}{l}10 \\
2.0\end{array}$ & 44 & 8.8 & $\begin{array}{r}194 \\
23\end{array}$ & $\begin{array}{l}31 \\
2.5\end{array}$ \\
\hline
\end{tabular}


RECHARGE OF BASALT AQUIFERS, THE DALLES, OREGON E53 from the Dalles area-Continued

\begin{tabular}{|c|c|c|c|c|c|c|c|c|c|c|c|c|}
\hline \multirow[b]{2}{*}{ 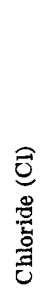 } & \multirow[b]{2}{*}{ 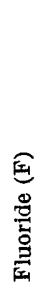 } & \multirow[b]{2}{*}{ 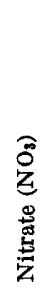 } & \multicolumn{2}{|c|}{$\begin{array}{l}\text { Dissolved } \\
\text { solids }\end{array}$} & \multicolumn{2}{|c|}{$\begin{array}{l}\text { Hardness } \\
\text { as } \mathrm{CaCO}_{3} \mathrm{CO}_{3}\end{array}$} & \multirow[b]{2}{*}{ 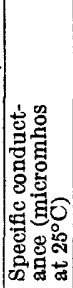 } & \multirow[b]{2}{*}{ 焉 } & \multirow[b]{2}{*}{ 홍 } & \multicolumn{2}{|c|}{$\begin{array}{c}\text { Dissolved } \\
\text { oxygen }\end{array}$} & \multirow[b]{2}{*}{ Remarks } \\
\hline & & & 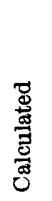 & 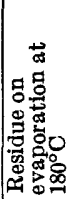 & 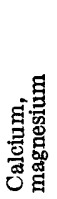 & 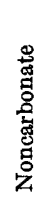 & & & & 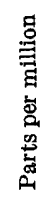 & 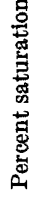 & \\
\hline & 1.3 & & & & 34 & 0 & 115 & 7.3 & "-.. & .3 & 2.5 & Sampled during pump- \\
\hline & 1.2 & & & & 24 & 0 & 70 & 7.3 & & & & Sampled following re- \\
\hline & 1.3 & & & & 24 & 0 & 71 & 7.4 & & & -... & Do. \\
\hline & 2.5 & & & & 26 & 0 & 74 & 7.0 & & ... & & Sampled during pump- \\
\hline & 1.0 & & & & 72 & 0 & 182 & 7.4 & & & & Do. \\
\hline & 1.0 & & 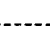 & & 58 & 0 & 150 & 7.8 & 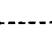 & & & Do. \\
\hline & 1.2 & & & & 38 & 0 & 110 & 7.4 & & & & Do. \\
\hline & 1.2 & & & & 34 & 0 & 106 & 7.5 & & & & Do. \\
\hline 5.0 & .2 & .6 & 126 & 118 & 79 & 3 & 204 & 7.8 & 5 & & & \\
\hline 6.0 & $\ldots$. & .05 & 249 & & 79 & & & & & & & Reported by Piper (1932, \\
\hline & 1.0 & & & & & & & & $<0.5$ & & & $\begin{array}{l}\text { Analysis by Chariton } \\
\text { Laboratories, Port- } \\
\text { land, Oreg. Turbidity } \\
<5 \text {. } \\
\text { Do. }\end{array}$ \\
\hline 6.0 & 1.0 & 0.0 & 260 & 249 & 70 & 0 & 335 & 8 & 0 & & & Carbonate $\left(\mathrm{CO}_{3}\right), 0$ \\
\hline $\begin{array}{l}6.0 \\
2.9\end{array}$ & $0^{.9}$ & $0^{1}$ & 295 & $\begin{array}{l}296 \\
100\end{array}$ & $\begin{array}{r}108 \\
20\end{array}$ & 0 & 402 & $\begin{array}{l}8.5 \\
7.3\end{array}$ & 0 & & & $\begin{array}{l}\text { Carbonate }\left(\mathrm{CO}_{3}\right), 6 \text {. } \\
\text { Analysis by Charlton } \\
\text { Laboratories, Port- } \\
\text { land, Oreg. Aluminum } \\
\text { (Al), 0.30 in effuent } \\
\text { from treatment plant. }\end{array}$ \\
\hline
\end{tabular}


TABLE 5. - Suspended sediment in waters sampled during artificial recharge study at The Dalles

[Unless otherwise noted, samples were collected at sampling tap on discharge line from pump; samples from reservoir shown with depth range were collected with an integrating sampler from pler in reservoir. Concentration given in parts per million. Asterisk indicates average of 2 or more consecutive samples]

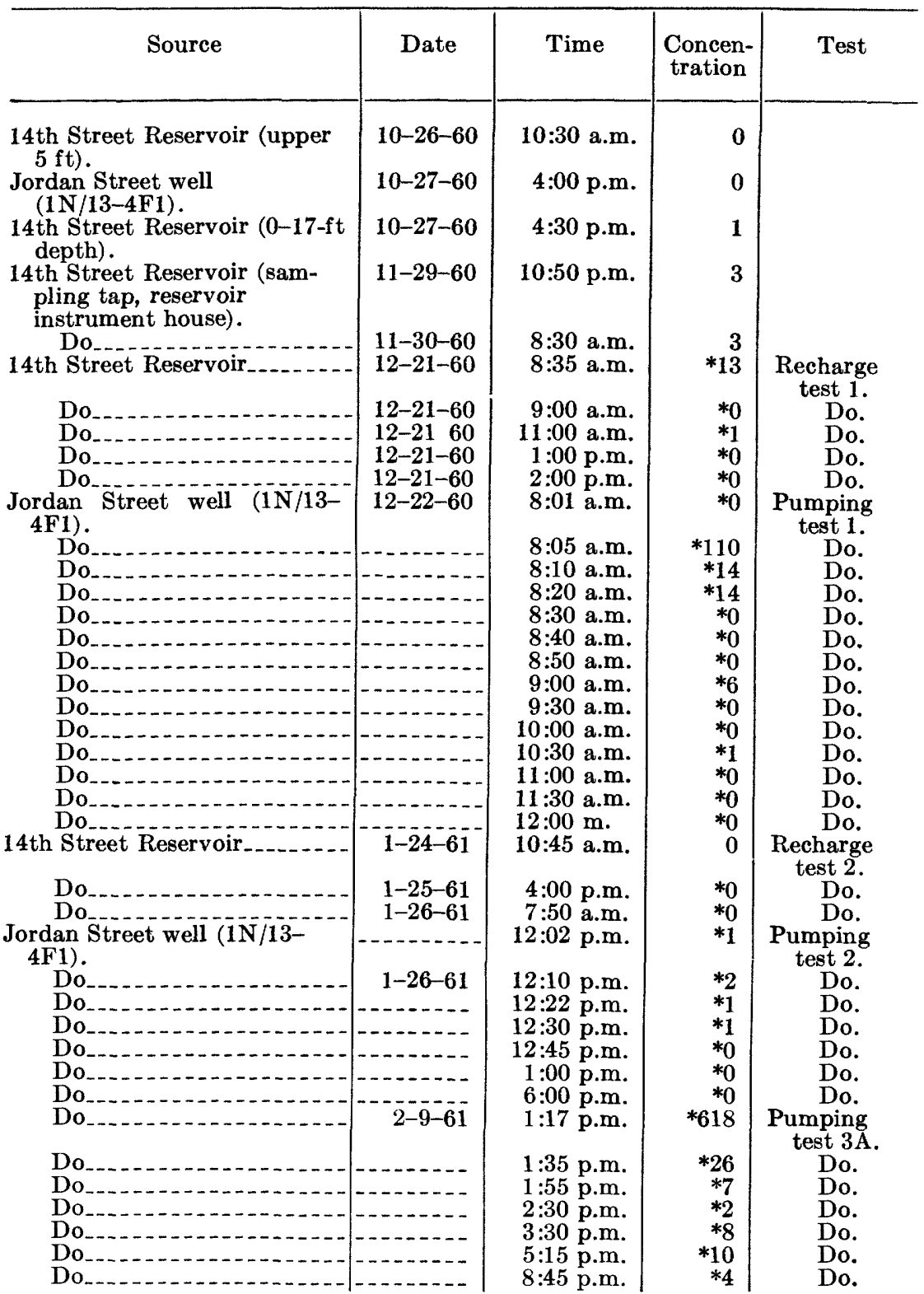


RECHARGE OF BASALT AQUIFERS, THE DALLES, OREGON E55

TABLE 5.-Suspended sediment in waters sampled during artificial recharge study at The Dalles-Continued

\begin{tabular}{|c|c|c|c|c|}
\hline Source & Date & Time & $\begin{array}{c}\text { Concen- } \\
\text { tration }\end{array}$ & Test \\
\hline 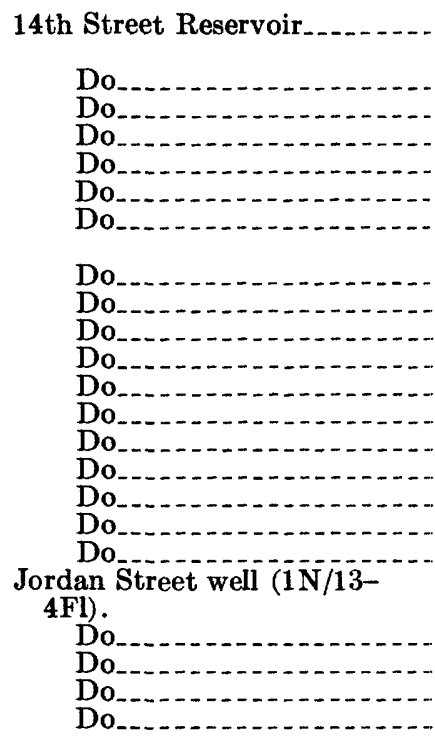 & $\begin{array}{r}4-4-61 \\
4-5-61 \\
4-6-61 \\
4-7-61 \\
4-8-61 \\
4-9-61 \\
4-10-61 \\
4-11-61 \\
4-12-61 \\
4-13-61 \\
4-14-61 \\
4-15-61 \\
4-16-61 \\
4-17-61 \\
4-18-61 \\
4-19-61 \\
4-20-61 \\
4-21-61 \\
4-24-61\end{array}$ & $\begin{array}{r}\text { 3:25 p.m. } \\
\text { 9:00 a.m. } \\
\text { 11:15 a.m. } \\
1: 15 \text { p.m. } \\
\text { 3:55 p.m. } \\
\text { 10:55 a.m. } \\
\text { 9:00 a.m. } \\
\\
\text { 10:50 a.m. } \\
\text { 12:55 p.m. } \\
\text { 3:50 p.m. } \\
\text { 8:35 a.m. } \\
11: 10 \text { a.m. } \\
\text { 4:20 p.m. } \\
10: 40 \text { a.m. } \\
3: 25 \text { p.m. } \\
\text { 8:30 a.m. } \\
\text { 10:50 a.m. } \\
2: 25 \text { p.m. } \\
\text { 3:31 p.m. } \\
\text { 3:40 p.m. } \\
5: 15 \text { p.m. } \\
7: 31 \text { p.m. } \\
\text { 11:15 p.m. }\end{array}$ & $\begin{array}{r}2 \\
2 \\
2 \\
2 \\
2 \\
2 \\
0 \\
2 \\
2 \\
2 \\
2 \\
0 \\
2 \\
2 \\
0 \\
0 \\
2 \\
2 \\
2 \\
6 \\
* 94 \\
* 8 \\
* 18 \\
* 3\end{array}$ & $\begin{array}{c}\text { Recharge } \\
\text { test 4. } \\
\text { Do. } \\
\text { Do. } \\
\text { Do. } \\
\text { Do. } \\
\text { Do. } \\
\text { Recharge } \\
\text { test 4. } \\
\text { Do. } \\
\text { Do. } \\
\text { Do. } \\
\text { Do. } \\
\text { Do. } \\
\text { Do. } \\
\text { Do. } \\
\text { Do. } \\
\text { Do. } \\
\text { Do. } \\
\text { Do. } \\
\text { Pumping } \\
\text { test 4A. } \\
\text { Do. } \\
\text { Do. } \\
\text { Do. } \\
\text { Do. }\end{array}$ \\
\hline
\end{tabular}

